\title{
Environmental influence on phytoplankton communities in the northern Benguela ecosystem
}

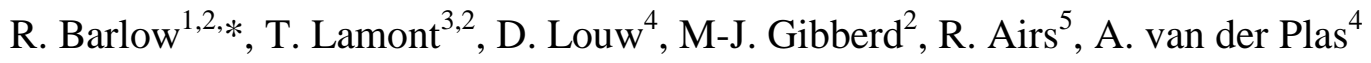 \\ ${ }^{1}$ Bayworld Centre for Research and Education, Cape Town, South Africa \\ ${ }^{2}$ Marine Research Institute \& Department of Oceanography, University of Cape Town, Cape Town, \\ South Africa \\ ${ }^{3}$ Branch: Oceans and Coastal Research, Department of Environmental Affairs, Cape Town, South Africa \\ ${ }^{4}$ National Marine Information and Research Centre, Swakopmund, Namibia \\ ${ }^{5}$ Plymouth Marine Laboratory, Plymouth, United Kingdom \\ *Corresponding author,e-mail: rgb.barlow@gmail.com
}

\begin{abstract}
An investigation of surface phytoplankton communities was undertaken on the shelf of the northern Benguela upwelling ecosystem during austral autumn (May) and spring (September) using microscopic identification and CHEMTAX analysis of pigment biomarkers on latitudinal transects at $20^{\circ} \mathrm{S}$ and $23^{\circ} \mathrm{S}$ up to 70 nautical miles offshore, and on a zigzag grid located between these transects. During May 2014, warmer, more saline water with a shallower upper mixed layer corresponding to periods of less intense offshore Ekman transport was encountered on the shelf. Satellite imagery indicated high biomass extending for a considerable distance from the coast, and CHEMTAX indicated diatoms dominating at most of the stations (52-92\%), although dinoflagellates were dominant at some inshore localities (5774\%). Species of Chaetoceros, Bacteriastrum and Cylindrotheca were the most abundant, with Pseudonitzschia seriata-group abundance being particularly high at a number of stations. In September 2014, more intense wind forcing resulted in a deeper upper mixed layer and stronger upwelling of colder, less saline water. Elevated phytoplankton biomass was confined close to the coast where diatoms accounted for most of the population (54-87\%), but small flagellates such as prasinophytes, haptophytes and cryptophytes, and the cyanobacterium Synechococcus, dominated the communities (58-90\%) further away from the coast. It is hypothesized that stronger upwelling and deeper vertical mixing in September 2014 were not conducive for wide-spread diatom growth, and that small flagellates populated the water column by being entrained from offshore onto the shelf in the upwelled water that moved in towards the coast.
\end{abstract}

Keywords: Phytoplankton, Pigments, Species, Hydrography, Benguela upwelling ecosystem

\section{Introduction}

The Benguela ecosystem off southwest Africa is one of the major upwelling systems in the world's ocean and is characterised by cold nutrient-rich water and high plankton productivity on the continental shelf (Nelson and Hutchings 1983; Shannon and Nelson 1996; Hutchings et al. 2009). The northern region of the ecosystem is located off Namibia $\left(17^{\circ}-29^{\circ} \mathrm{S}\right)$ and upwelling is driven by intense along-shore southeasterly winds, facilitated by low eddy activity and a shallow mixed layer on a relatively wide shelf (Lachkar and Gruber 2012). There are seasonal fluctuations in the wind field and the climatology indicates peaks in wind stress during April-May and August-September (Louw et al. 2016). There is a consequent seasonality in upwelling and surface water temperatures, with lower surface temperatures in the period June to October and higher surface temperatures during December to May (Louw et al. 2016).

In response to changing upwelling conditions, phytoplankton biomass is highly variable on the Namibian shelf. Previous investigations by Estrada and Marrasé (1987) demonstrated patchy distributions of phytoplankton, with chlorophyll $a$ levels of $20 \mathrm{mg} \mathrm{m}^{-3}$ at various localities near the coast in $15^{\circ}-16^{\circ} \mathrm{C}$ water. Barlow et al. (2001) measured 0.3-18.5 $\mathrm{mg} \mathrm{m}^{-3}$ on the shelf south of Walvis Bay in winter, with the high levels being observed at shallow stations, while chlorophyll $a$ ranging from $18.4 \mathrm{mg} \mathrm{m}^{-3}$ near the coast $\left(11^{\circ}-12^{\circ} \mathrm{C}\right.$ water) to $0.6 \mathrm{mg} \mathrm{m}^{-3} 100 \mathrm{~km}$ offshore $\left(16^{\circ}-17^{\circ} \mathrm{C}\right.$ water) were observed during a spring 
survey between $19^{\circ} \mathrm{S}$ and $25^{\circ} \mathrm{S}$ (Barlow et al. 2006). In a recent 12 year in situ study on a transect at $23^{\circ} \mathrm{S}$ in the centre of the Namibian upwelling system, Louw et al. (2016) observed that major blooms where chlorophyll $a$ was $>18 \mathrm{mg} \mathrm{m}^{-3}$ occurred in 5 of the 12 years and minor blooms $\left(10-13 \mathrm{mg} \mathrm{m}^{-3}\right)$ were observed every year. Maxima usually developed inshore each year with peaks in April (autumn), August (winter) and December (summer). The forcing mechanisms driving these patterns are complex and include dynamic variability in wind, temperature, mixing, stratification and thermocline development, and nutrient availability. Similar changes in chlorophyll $a$ occur in the upwelling ecosystem off central Chile where Anabalon et al. (2016) observed seasonal variability at a coastal site with two maxima of 8-10 mg $\mathrm{m}^{-3}$ in the spring (October) and summer (January). In the upwelling system off central Oregon Du et al. (2015) also noted that peaks in chlorophyll $a$ of $15-20 \mathrm{mg} \mathrm{m}^{-3}$ occurred in the boreal summer months of July and August.

Phytoplankton composition of diatoms and dinoflagellates was originally identified by microscopy in the 1960's (Kollmer 1962, 1963) and by Kruger (1980), who also noted many small flagellates that were difficult to identify and quantify by microscopy. More recently community structure has also been elucidated using pigment indices and a spring survey during 2000 by Barlow et al. (2006) indicated diatoms dominating closer to the coast, while small flagellates were generally more prominent in the offshore communities. Pigments have been useful to characterize phytoplankton populations in the southern Benguela ecosystem, where fucoxanthin, peridinin and zeaxanthin are biomarkers of diatoms, dinoflagellates and cyanobacteria, respectively. 19'-Hexanoyloxyfucoxanthin (haptophytes), 19'butanoyloxyfucoxanthin (pelagophytes), chlorophyll $b$ (prasinophytes) and alloxanthin (cryptophytes) are useful biomarkers for the small flagellates (Barlow et al. 2001, 2005, Fishwick et al. 2006). Microscopy revealed that the small flagellates in the 2000 spring survey were dominated by Emiliania huxleyi, while a substantially calcified E. huxleyi morphotype was also observed inshore immediately succeeding the decline in the coastal diatom blooms (Henderiks et al. 2012).

Investigations on succession have demonstrated a transition from dinoflagellates, coccolithophores and microflagellates in newly upwelled water to diatom dominance in matured upwelled water, and a change from diatoms to dinoflagellates in aged water (Hansen et al. 2014). In a complementary study in shipboard mesocosms, it was found that diatoms dominated in newly upwelled water, but autotrophic and heterotrophic dinoflagellates were then dominant at the matured stage (Wasmund et al. 2014). Water types were originally defined for the southern Benguela ecosystem where newly upwelled water had temperatures of $<10^{\circ} \mathrm{C}$ and nitrate concentrations of $15-30 \mathrm{mmol} \mathrm{m}^{-3}$, matured upwelled water temperatures were $10-15^{\circ} \mathrm{C}$ and nitrate levels were $2-15 \mathrm{mmol} \mathrm{m}^{-3}$, while aged water contained low concentrations of nitrate $\left(<2 \mathrm{mmol} \mathrm{m}^{-3}\right)$ and temperatures of $12-16^{\circ} \mathrm{C}$ (Barlow 1982a). Communities were observed to be in an active phase of growth in newly upwelled and mature water but were in a slowgrowing phase in aged water. A study by Louw et al. (2017) noted that the diatom genus, Pseudonitzschia, occurs frequently on the central Namibian coast and blooms developed in mature water when there was a decrease in wind stress and upwelling.

The high phytoplankton biomass off Namibia has sustained higher trophic levels and a rich marine fishery, but there has been a decline in commercial fish catches mainly due to overfishing (Finney et al. 2010). Furthermore, global climate change may have an impact on the Benguela ecosystem through atmospheric forcing (Bakun et al. 2010) and negatively affect both environmental and plankton patterns with consequent repercussions for the fragile fisheries industry. Under a warming scenario, phytoplankton composition could shift from diatom dominance to mixed communities where small flagellates and prokaryotes might contribute a greater proportion to the biomass, or perhaps become dominant under certain conditions. This would have an impact on zooplankton communities and Verheye et al (2016) report a shift from large to smaller zooplankton in the Benguela ecosystem since the mid-1990s, which in turn is likely to have an impact on higher trophic levels such as pelagic and demersal fish. The contribution of flagellates and prokaryotes to phytoplankton populations in the contemporary Namibian ecosystem is not well understood and an opportunity arose to examine community structure in more detail during two research cruises on the central shelf during May and September 2014. The approach was to 
collect surface samples for phytoplankton pigments and analyse the detailed pigment data using the statistical technique of CHEMTAX (Mackey et al. 1996; Higgins et al. 2011). CHEMTAX yields information about the contribution to the total chlorophyll $a$ (TChla) by the various flagellates mentioned above as well as the diatoms, dinoflagellates and prokaryotes (Higgins et al., 2011). Samples for microscopic analysis were also taken to elucidate details of the dominant diatom and dinoflagellate species. The objective was to examine the changing proportions of diatoms, dinoflagellates, flagellates and prokaryotes in surface waters at the time of the research cruises, and assess the impact of different seasonal environmental conditions on community structure.

\section{Methods}

\section{Hydrography and sampling}

The research cruises were undertaken on the Namibian shelf during 9-15 May and 8-13 September 2014 respectively. Hydrographic measurements and sampling were conducted on latitudinal transects located at $20^{\circ} \mathrm{S}$ and $23^{\circ} \mathrm{S}$ at $8-9$ stations varying from $2-70 \mathrm{~nm}$ (nautical miles) from the coast (Figure 1). In addition, further measurements and sampling were conducted at stations on a zigzag grid (ZZ1-ZZ14) located between $20^{\circ} \mathrm{S}$ and $23^{\circ} \mathrm{S}$ (Figure 1). The water column was profiled for temperature and salinity utilizing a Seabird CTD that was maintained regularly and calibrated according to the manufacturer's instructions. Nutrient samples $(50 \mathrm{ml})$ were drawn from the CTD rosette bottles at $10 \mathrm{~m}$ or $20 \mathrm{~m}$ depth intervals on the $20^{\circ} \mathrm{S}$ and $23^{\circ} \mathrm{S}$ transects only, filtered on board, and stored frozen for later analysis ashore using standard auto-analyser techniques (Mostert 1983). Surface seawater samples within the upper 2-5 m $(200 \mathrm{ml})$ were taken for species identification only at the $20^{\circ} \mathrm{S}$ and $23^{\circ} \mathrm{S}$ stations and preserved with $5 \mathrm{ml}$ of 40\% formaldehyde (Throndsen 1978). Further surface samples were drawn for pigment analysis (1000 $\mathrm{ml}$ ) at the $20^{\circ} \mathrm{S}$ and $23^{\circ} \mathrm{S}$ stations, and at the $\mathrm{ZZ}$ stations, and filtered through GFF filters that were stored frozen at $-80^{\circ} \mathrm{C}$ for analysis ashore. The depth of the upper mixed layer $\left(\mathrm{Z}_{\mathrm{m}}\right)$ was determined as the depth where the local change in density was $\geq 0.03 \mathrm{~kg} \mathrm{~m}^{-3}$ using density profiles and a threshold gradient criterion (Thomson and Fine 2003).

Ekman transport at $20^{\circ} \mathrm{S}$ and $23^{\circ} \mathrm{S}$ was computed from daily NCEP-DOE Reanalysis 2 meridional wind vectors according to Lamont et al. (2017). Wind vectors were rotated to account for the orientation of the coastline and wind stress was computed using the non-linear drag coefficient defined by Large and Pond (1981) and modified by Trenberth et al. (1990) for low wind speeds. Ekman transport $\left(\mathrm{m}^{3} \mathrm{~s}^{-1} 100 \mathrm{~m}^{-1}\right.$ of coastline) was then computed, with positive values indicating offshore transport (upwelling), and negative values representing onshore transport (downwelling). Daily values were summed to provide an estimate of the monthly cumulative offshore Ekman transport at $20^{\circ} \mathrm{S}$ and $23^{\circ} \mathrm{S}$. Standard monthly-averaged chlorophyll $a$ data and Sea Surface Temperature (SST) from MODIS-Aqua (v2018.0), at $4.5 \mathrm{~km}$ spatial resolution (NASA 2018), was downloaded for May and September 2014 from the Ocean Biology Processing Group (OBGP) at NASA's Goddard Space Flight Center (GSFC; http://oceancolor.gsfc.nasa.gov). It was difficult to obtain clear enough satellite images of daily or weekly-averaged chlorophyll $a$ and SST due to extensive cloud cover and fog along the Namibian coast and shelf and therefore only monthly-averaged images were found to be suitable.

\section{Phytoplankton identification}

Species identification and counts were performed with a Zeiss Axiovert 200 inverted light microscope (Utermöhl 1958). Prior to counting, formalin-preserved samples were settled in a $25 \mathrm{ml}$ chamber for $24 \mathrm{~h}$. Concentrations of cells were calculated using the equation of Utermöhl (1958) and counting of at least 400 cells with a precision of $\pm 10 \%$. Where species occurred in low concentrations, 50-200 cells were counted, providing a precision of 15-30\% for quantitative estimates (Andersen and Throndsen 2004). 
Pigments were extracted in $90 \%$ acetone, aided by the use of ultrasonication, clarified by centrifugation and filtration, and analysed by HPLC (ThermoScientific Accela) using a Waters Symmetry C8 column $\left(150 \times 2.1 \mathrm{~mm}, 3.5 \mu \mathrm{m}\right.$ particle size, thermostated at $25^{\circ} \mathrm{C}$ ) according to Zapata et al. (2000). Pigments were detected at 440 and $660 \mathrm{~nm}$ and identified by retention time and on-line diode array spectra. Monovinyl chlorophyll $a$ standard was obtained from Sigma-Aldrich Ltd and other pigment standards were purchased from the DHI Institute for Water and Environment, Denmark. Quality assurance protocols followed Van Heukelem and Hooker (2011). The method separates divinyl and monovinyl chlorophyll $a$, zeaxanthin and lutein, but does not resolve divinyl and monovinyl chlorophyll $b$. Limits of detection were of the order of $0.001 \mathrm{mg} \mathrm{m}^{-3}$.

To determine community composition, pigment data was analysed by CHEMTAX (Mackey et al. 1996) following Higgins et al. (2011), with chemotaxonomic groups being identified according to Jeffrey et al. (2011). An assumption made using CHEMTAX is that the pigment:chlorophyll $a$ ratios are constant across all the samples within each analysis. Therefore analysis was performed separately for each cruise such that all samples for May 2014 were run together, and then all samples for September 2014 were run together. Pigment starting ratios were obtained from Higgins et al. (2011) and Table 1 indicates the identified functional groups and the various starting and output ratios for each group. To ease the presentation of the chemotaxonomic data, diatoms-1 and -2 were combined into a collective diatom group, and prasinophytes-1 and -3 were combined into a collective prasinophyte group. Data for chlorophytes is not presented as CHEMTAX indicated that the contribution of this group was very low.

CHEMTAX outputs are the fraction of chlorophyll $a$ attributed to each functional group specified in the matrix. The HPLC method separated monovinyl chlorophyll $a$ allomer, monovinyl chlorophyll $a$, monovinyl chlorophyll $a$ epimer and chlorophyllide $a$, and in CHEMTAX the sum of all 4 was used as the total chlorophyll $a$ concentration (TChla). Chlorophyllide $a$ was included as it can be generated from artificial degradation of chlorophyll $a$ by chlorophyllase activity during sample handling and extraction when diatoms are present (Jeffrey and Hallegraeff 1987). The software may not discover the best global solution if it encounters local minima in the process. To circumvent this possibility, multiple starting points were used. Sixty-nine further pigment ratio tables were generated by multiplying each cell of the initial table by a randomly determined factor $\mathrm{F}$, calculated as:

$$
\mathrm{F}=1+\mathrm{S} \times(\mathrm{R}-0.5)
$$

where $\mathrm{S}$ is a scaling factor of 0.7 , and $\mathrm{R}$ is a random number between 0 and 1 generated using the Microsoft Excel RAND function (Wright et al., 2009). Each of the 69 ratio tables was used as the starting point for a CHEMTAX optimization. The solution with the smallest residual was used for the estimated taxonomic abundance.

\section{Results}

\section{Hydrography}

Monthly-averaged satellite images are presented to set the geographic and hydrographic context for the study area, indicating that warmer water prevailed during May 2014 compared to cooler water conditions in September 2014 (Figure 1a and c). The chlorophyll $a$ image for May 2014 revealed high levels along the coast between $25^{\circ} \mathrm{S}$ and $19^{\circ} \mathrm{S}$, with an offshore extension to the $\mathrm{ZZ}$ stations (Figure 1b). In September 2014, chlorophyll $a$ was elevated inshore from Walvis Bay to Toscanini, with patchy lower concentrations between $20^{\circ} \mathrm{S}$ and $21^{\circ} \mathrm{S}$ (Figure 1d). Levels were much lower further offshore between $23^{\circ} \mathrm{S}$ and $20^{\circ} \mathrm{S}$.

Daily offshore Ekman transport showed a decreasing trend during the cruise period in May 2014, with values decreasing from $130 \mathrm{~m}^{3} \mathrm{~s}^{-1} 100 \mathrm{~m}^{-1}$ on 9 May to $18 \mathrm{~m}^{3} \mathrm{~s}^{-1} 100 \mathrm{~m}^{-1}$ on 13 May at $20^{\circ} \mathrm{S}$, increasing slightly to $55 \mathrm{~m}^{3} \mathrm{~s}^{-1} 100 \mathrm{~m}^{-1}$ by 15 May (Figure 2a). Similarly, Ekman transport decreased from $163 \mathrm{~m}^{3} \mathrm{~s}^{-}$ 
${ }^{1} 100 \mathrm{~m}^{-1}$ on 9 May to $11 \mathrm{~m}^{3} \mathrm{~s}^{-1} 100 \mathrm{~m}^{-1}$ on 12 May at $23^{\circ} \mathrm{S}$, then increasing to $51 \mathrm{~m}^{3} \mathrm{~s}^{-1} 100 \mathrm{~m}^{-1}$ by 15 May (Figure 2b). In contrast, the opposite pattern was observed during the cruise in September 2014, with offshore Ekman transport increasing from $5 \mathrm{~m}^{3} \mathrm{~s}^{-1} 100 \mathrm{~m}^{-1}$ on 8 September to $98 \mathrm{~m}^{3} \mathrm{~s}^{-1} 100 \mathrm{~m}^{-1}$ on 10 September at $20^{\circ} \mathrm{S}$, and then fluctuating between 30 and $70 \mathrm{~m}^{3} \mathrm{~s}^{-1} 100 \mathrm{~m}^{-1}$ during 11-13 September (Figure 2c). Ekman transport also increased from $32 \mathrm{~m}^{3} \mathrm{~s}^{-1} 100 \mathrm{~m}^{-1}$ on 8 September 2014 to 170,138 and $142 \mathrm{~m}^{3} \mathrm{~s}^{-1} 100 \mathrm{~m}^{-1}$ on 10,11 and 12 September respectively at $23^{\circ} \mathrm{S}$ (Figure 2d). Monthly values of cumulative offshore Ekman transport at $23^{\circ} \mathrm{S}$ indicated that upwelling-favourable winds during September $2014\left(4003 \mathrm{~m}^{3} \mathrm{~s}^{-1} 100 \mathrm{~m}^{-1}\right)$ were nearly twice the intensity of that in May $2014\left(2295 \mathrm{~m}^{3} \mathrm{~s}^{-1}\right.$ $100 \mathrm{~m}^{-1}$ ). The difference in monthly cumulative offshore Ekman transport at $20^{\circ} \mathrm{S}$ was less, being 2424 $\mathrm{m}^{3} \mathrm{~s}^{-1} 100 \mathrm{~m}^{-1}$ in September 2014 compared to $1520 \mathrm{~m}^{3} \mathrm{~s}^{-1} 100 \mathrm{~m}^{-1}$ in May 2014, but still indicating greater offshore transport in the spring.

In situ surface temperature and salinity data indicated warmer, more saline waters at the surface on the $20^{\circ} \mathrm{S}$ and $23^{\circ} \mathrm{S}$ transects during May 2014. Along $20^{\circ} \mathrm{S}, 15-16^{\circ} \mathrm{C}$ water was observed inshore at the surface and $18-19^{\circ} \mathrm{C}$ offshore between 40 and $70 \mathrm{~nm}$ (Figure $3 \mathrm{a}$ ), while at $23^{\circ} \mathrm{S}$ surface temperatures were $14-15^{\circ} \mathrm{C}$ inshore and $15-17^{\circ} \mathrm{C}$ offshore (Figure $3 b$ ). Surface salinities of 35.4-35.5 inshore and 35.5-35.6 offshore $\left(40-70 \mathrm{~nm}\right.$ ) were noted for the $20^{\circ} \mathrm{S}$ transect (Figure 4a), while salinities of 35.2-35.3 prevailed across the $23^{\circ} \mathrm{S}$ transect in May 2014 (Figure $4 \mathrm{~b}$ ). The estimated depth of the upper mixed layer varied from $25-75 \mathrm{~m}$ along $20^{\circ} \mathrm{S}$ and was $<50 \mathrm{~m}$ on $23^{\circ} \mathrm{S}$ (Figures 3, 4). Lower surface temperatures and salinities were observed in September 2014 , with $12-13^{\circ} \mathrm{C}$ water close inshore on $20^{\circ} \mathrm{S}, 13-14^{\circ} \mathrm{C}$ from 2$30 \mathrm{~nm}$, and $14-15^{\circ} \mathrm{C}$ between $30 \mathrm{~nm}$ and $70 \mathrm{~nm}$ (Figure $3 \mathrm{c}$ ). Along $23^{\circ} \mathrm{S}$, surface temperatures were 11.5 $13^{\circ} \mathrm{C}$ inshore up to $25 \mathrm{~nm}$ from the coast and $13-15^{\circ} \mathrm{C}$ further offshore (Figure $3 \mathrm{~d}$ ). Surface salinities of 35.1-35.2 were noted from the coast to $40 \mathrm{~nm}$ on $20^{\circ} \mathrm{S}$ and $35.2-35.3$ beyond $40 \mathrm{~nm}$ (Figure 4c), while salinities of 34.9-35.0 were measured out to $50 \mathrm{~nm}$ on $23^{\circ} \mathrm{S}$ and 35.0-35.1 between 50 and $70 \mathrm{~nm}$ (Figure $4 \mathrm{~d})$. Upper mixed layers were $<50 \mathrm{~m}$ on $20^{\circ} \mathrm{S}$ in September 2014 , but varied from $15-100 \mathrm{~m}$ on $23^{\circ} \mathrm{S}$ (Figures 3 and 4).

Two longitudinal transects were designated for the $\mathrm{ZZ}$ stations, a coastal transect for the odd numbered stations, and an offshore transect for the even numbered stations (Figure 1). Surface temperatures were uniform at $14^{\circ} \mathrm{C}$ along the coastal transect in May 2014 (Figure 5a) and varied from $12.5-14^{\circ} \mathrm{C}$ in September 2014 (Figure 5c). Salinity was 35.3-35.4 in May 2014 and 35.1-35.2 in September 2014 (data not shown). The upper mixed layer on this coastal transect was 17-18 m in May 2014, but only $3 \mathrm{~m}$ at ZZ1, and varied between $5 \mathrm{~m}$ and $30 \mathrm{~m}$ in September 2014 (Figure 5a, c). Surface temperatures were higher along the offshore $\mathrm{ZZ}$ transect, being $16-17^{\circ} \mathrm{C}$ in May 2014 (Figure $5 \mathrm{~b}$ ) and $14-15^{\circ} \mathrm{C}$ in September 2014 (Figure 5d). Surface salinity varied from 35.3-35.5 in May 2014 and was lower in September 2014 at 35.0-35.2 (data not shown). Mixed layer depths on the offshore ZZ transect were $<50 \mathrm{~m}$ during both May and September 2014 (Figure 5b, d).

\section{Phytoplankton species}

Only the dominant species of diatoms and dinoflagellates on the $20^{\circ} \mathrm{S}$ and $23^{\circ} \mathrm{S}$ transects are listed in Table 2 as a more detailed account of all species will be reported elsewhere. The criterion for dominance was selected as the highest abundance for 1-3 species at each station compared to other species that had lower abundances. Dominant cell counts varied widely, however, and examples are the $30 \mathrm{~nm}$ station on $20^{\circ} \mathrm{S}$ in May 2014 where abundance was $1.39-2.67 \times 10^{6}$ cells $\mathrm{L}^{-1}$, while at the $50 \mathrm{~nm}$ station on $23^{\circ} \mathrm{S}$, cell counts were $1.05-1.14 \times 10^{3}$ cells $\mathrm{L}^{-1}$ (Table 2).

Diatoms were dominated by various species on each transect and the Pseudo-nitzschia seriata-group, Chaetoceros curvisetus and Chaetoceros debilis were the most abundant up to $30 \mathrm{~nm}$ on $20^{\circ} \mathrm{S}$ during May 2014. Thalassiosira gravida, Bacteriastrum delicatulum, Bacteriastrum hyalinum, Cylindrotheca closterium, Pseudo-nitzschia seriata-group, Rhizosolenia robusta and a Thalassiosira sp were the dominant diatoms from 40-70 nm, with the particular details for each station presented in Table 2. These species were also the dominant diatoms on $23^{\circ} \mathrm{S}$ in May 2014 and the Pseudo-nitzschia seriata-group was 
particularly dominant at six of the nine stations (Table 2). The dominant dinoflagellates on the $20^{\circ} \mathrm{S}$ transect included Ceratium spp., Prorocentrum micans, Corythodinium tesselatus, Gyrodinium spp., Protoperidinium pallidum and Protoperidinium spp., although unidentified dinoflagellates were also present at some of the stations. For $23^{\circ} \mathrm{S}$, Prorocentrum micans, Protoperidinium spp. and Scrippsiella trochoidea were the dominant species, but the abundance of naked dinoflagellates and unidentified dinoflagellates appeared to be greater on this transect (Table 2).

A change in diatom species was observed in September 2014 where the dominant species on $20^{\circ} \mathrm{S}$ were Thalassiosira gravida, Pseudo-nitzschia seriata-group, Thalassiosira rotula, Leptocylindrus danicus, Thalassiosira anguste-lineata, Chaetoceros decipiens and Chaetoceros didymus, with varying abundances between stations (Table 2). Different species were generally dominant on $23^{\circ} \mathrm{S}$ that included Skeletonema japonica, Navicula spp., Pseudo-nitzschia delicatissima-group, Chaetoceros curvisetus, Chaetoceros constrictus, Chaetoceros convolutes, Chaetoceros atlanticus and Pseudo-nitzschia seriatagroup (Table 2). There was also a general change in dinoflagellates for September 2014 and Gyrodinium spp., Gymnodenium spp., Protoperidinium spp., Scrippsiella trochoidea, Noctiluca scintillans, Ceratium furca, Dinophysis fortii, Prorocentrum triestinum and Dinophysis acuminate were the dominant species on $20^{\circ} \mathrm{S}$. Four of these dinoflagellates were also dominant on $23^{\circ} \mathrm{S}$ in addition to Prorocentrum triestinum and Protoperidinium oblongum (Table 2). Unidentified dinoflagellates were also present in significant numbers at some stations on both the $20^{\circ} \mathrm{S}$ and $23^{\circ} \mathrm{S}$ transects.

\section{CHEMTAX}

The pattern of community structure as determined by CHEMTAX is presented together with surface temperature and nutrient data in Figures 6 to 9. Surface temperatures on the $20^{\circ} \mathrm{S}$ transect were $15^{\circ}-18^{\circ} \mathrm{C}$ in May 2014 compared to $13^{\circ}-14.5^{\circ} \mathrm{C}$ in September 2014 and there was a general decrease in the concentrations of nitrates and silicates from inshore to offshore, although they did not appear to reach limiting levels of $<1 \mathrm{mmol} \mathrm{m}^{-3}$ (Barlow et al. 2006) as all concentrations were $>2 \mathrm{mmol} \mathrm{m}^{-3}$ (Figure 6a, d). TChla concentrations ranged from 1.1-3.4 $\mathrm{mg} \mathrm{m}^{-3}$ in May 2014, but was more variable in September 2014 where TChla was $2.2-8.0 \mathrm{mg} \mathrm{m}^{-3}$ at inshore stations and $0.8-2.6 \mathrm{mg} \mathrm{m}^{-3}$ between 10 and $70 \mathrm{~nm}$ offshore (Figure 6b, e). Phytoplankton communities in May 2014 were dominated by dinoflagellates at the 2, 10 and $20 \mathrm{~nm}$ stations (57-74\%) and by diatoms at the $30-70 \mathrm{~nm}$ stations (71-92\%), with the small flagellate (haptophytes, pelagophytes, cryptophytes, prasinophytes) and prokaryote (Synechococcus) groups contributing $<20 \%$ (Figure $6 \mathrm{c}$ ). The diatom proportion was $45-88 \%$ at the $2-60 \mathrm{~nm}$ stations in September 2014, but the flagellate contribution was $76 \%$ at the $70 \mathrm{~nm}$ station, with prasinophytes accounting for at least half (Figure 6f).

On the $23^{\circ} \mathrm{S}$ transect, surface temperatures were also higher in May $2014\left(14^{\circ}-16.5^{\circ} \mathrm{C}\right)$ than September $2014\left(12^{\circ}-14.5^{\circ} \mathrm{C}\right.$ ), with highly variable nitrate and silicate concentrations that were $>2 \mathrm{mmol} \mathrm{m}^{-3}$ (Figure $7 \mathrm{a}, \mathrm{d})$. TChla levels were $1.2-2.4 \mathrm{mg} \mathrm{m}^{-3}$ across the transect in May 2014 and $0.8-2.2 \mathrm{mg} \mathrm{m}^{-3}$ in September 2014 (Figure 7b, e). Diatoms dominated the populations on the transect in May 2014 (47$78 \%$ ), although dinoflagellates and pelagophytes contributed $24 \%$ and $21 \%$ respectively at the $2 \mathrm{~nm}$ station and dinoflagellates $29 \%$ at $30 \mathrm{~nm}$ (Figure 7c). Flagellates were dominant in September 2014 (56$100 \%$ ) although diatoms were $55 \%$ at the $20 \mathrm{~nm}$ station (Figure 7f). Prasinophytes accounted for most of the flagellates at the 2-50 nm stations, Synechococcus contributed $42 \%$ and $30 \%$ at $40 \mathrm{~nm}$ and $50 \mathrm{~nm}$, while haptophytes contributed $32 \%$ at the $70 \mathrm{~nm}$ station.

No nutrient data was available for the $\mathrm{ZZ}$ stations but surface temperatures were $13.9^{\circ}-14.7^{\circ} \mathrm{C}$ at the inshore ZZ stations in May and $12.4^{\circ}-13.7^{\circ} \mathrm{C}$ in September 2014 (Figure 8a, d). The highest TChla levels were observed at the southern ZZ1 station in both May $\left(4.5 \mathrm{mg} \mathrm{m}^{-3}\right)$ and September $2014\left(7.7 \mathrm{mg} \mathrm{m}^{-3}\right)$, with lower TChla at the other inshore ZZ stations (Figure 8b, e). Dinoflagellates were generally the dominant phytoplankton group (47-70\%) in May 2014 (Figure 8e), but in September 2014 the diatoms were mostly dominant (33-73\%) together with some of the flagellates (Figure 8f). Prasinophytes 
contributed $28-45 \%$ at the ZZ1, 3, 5 and 7 stations, and cryptophyes were $19-32 \%$ at the ZZ 11 and 13 stations (Figure 8f).

Temperatures at the offshore $\mathrm{ZZ}$ stations were higher in May $\left(16.0^{\circ}-17.0^{\circ} \mathrm{C}\right)$ compared to September 2014 $\left(14.2^{\circ}-15.2^{\circ} \mathrm{C}\right)$ (Figure 9a, d), and overall surface waters at these offshore stations were also warmer than at the inshore stations during both months. TChla at these offshore stations was $1.2-10.2 \mathrm{mg} \mathrm{m}^{-3}$ in May 2014 but lower in September $\left(0.7-1.5 \mathrm{mg} \mathrm{m}^{-3}\right.$; Figure 9b, e). Diatoms dominated $52-92 \%$ at all stations in May 2014 (Figure 9e) but the flagellates were collectively more dominant (59-97\%) in September 2014 (Figure 9f). While the diatoms were dominant at ZZ2 (57\%), the haptophytes and prasinophytes contributed $13-50 \%$ and $12-44 \%$ respectively at the other offshore stations, and the Synechococcus proportion was $9-23 \%$ at some of these stations (Figure 9f).

\section{Discussion}

Previous studies in the southern Benguela ecosystem identified three stages in the evolution of upwelled water, namely newly upwelled water, matured water and aged water (Barlow 1982a, 1982b; Brown and Hutchings 1987). More recently, in a study of phytoplankton succession in the northern Benguela, Hansen et al. (2014) developed more suitable hydrographic criteria for these stages for the northern Benguela. Applying the criteria of Hansen et al. (2014) to the current data indicated that the water masses in May 2014 were in a late mature to aged stage on the $20^{\circ} \mathrm{S}, 23^{\circ} \mathrm{S}$ and $\mathrm{ZZ}$ transects. This is in agreement with the offshore Ekman transport that exhibited a decreasing pattern during the May cruise period, and implied that the sampling was conducted during the declining phase of an upwelling event. During September 2014, the Hansen et al. (2014) criteria suggested that the water was in a newly upwelled stage, with a tendency towards the mature stage at the outer three stations on $20^{\circ} \mathrm{S}$ and $23^{\circ} \mathrm{S}$. This corresponded well with the offshore Ekman transport that displayed an increasing pattern during the cruise period in September, implying that sampling took place during the early phase of an upwelling event.

Hansen et al. (2014) observed diatom dominance in matured upwelled water, with a decline in diatoms and a succession to domination by dinoflagellates in the later stage of aged water. The CHEMTAX analysis of pigment data in this study indicated that diatoms were also dominant in aged water at most of the stations during May 2014, although dinoflagellates were dominant at the three inshore stations on $20^{\circ} \mathrm{S}$ and at the inshore $\mathrm{ZZ}$ stations (Figures 6 and 8). Mixed populations of nanoflagellates, coccolithophores and dinoflagellates were observed in newly upwelled water by Hansen et al. (2014). Similarly, small flagellates tended to be dominant in the newly upwelled water during September 2014, although diatoms and dinoflagellates were present in lower proportions. Prasinophytes and haptophytes contributed the greater proportion of the nanoflagellate component, and there was also a substantial proportion of the prokaryote Synechococcus (Figures 7 and 9). Thus, even though this investigation could only provide a "snapshot" of two stages of upwelling, there are similarities between the results of Hansen et al. (2014) for August-September 2011 and the observations here for May and September 2014. Although only surface characteristics are reported, Barlow et al. (2006) demonstrated that these communities are representative of the population within the water column for stations closer to the coast, but for stations towards the shelf edge the dominance of small flagellates in the upper mixed layer usually decreased at deeper depths where diatoms tended to be more dominant.

While CHEMTAX analysis was useful for indicating change in the bulk proportion of phytoplankton groups, microscopy provided details about the differences in species of diatoms and dinoflagellates between the two periods of investigation. The dinoflagellates in May 2014 were mostly unidentified species that included naked dinoflagellates, but more identifiable species were observed in September 2014. For the diatoms, species of Chaetoceros, Bacteriastrum and Cylindrotheca were dominant during May 2014, with Pseudo-nitzschia seriata-group abundance being particularly high at a number of stations on the $20^{\circ} \mathrm{S}$ and $23^{\circ} \mathrm{S}$ transects (Table 2). In contrast, dominant diatoms in September 2014 included species of Thalassiosira and Leptocylindrus, with Chaetoceros and Pseudo-nitzschia species at a few stations. Hansen et al. (2014) also noted that Pseudo-nitzschia seriata-group was abundant in mature 
upwelled water, together with species of Chaetoceros and Thalassiosira, but dinoflagellates of the order Gymnodiniales were dominant in aged water. Interestingly, small phytoplankton characterized the inshore newly upwelled water in August-September 2011 where Emiliania huxleyi and species of Phaeocystis, Pyramimonas and Pseudopedinella contributed a high percentage (Hansen et al. 2014). The prevalence of Pseudo-nitzschia species in Namibian waters (Kollmer 1963; Kruger 1980; Hansen et al. 2014) is of concern because they can be toxic to higher trophic levels. A 14 year study on the $23^{\circ} \mathrm{S}$ transect revealed blooms of Pseudo-nitzschia occurring in $13-16^{\circ} \mathrm{C}$ water, with the climatology showing an increase during austral summer, while a maximum can be attained during May-July (Louw et al. 2017). Pseudo-nitzschia blooms occurred during periods of low wind stress and weak upwelling (Louw et al. 2017), complementing the observations in this study where high Pseudo-nitzschia cell counts were observed under conditions of decreasing Ekman transport in May 2014.

This investigation indicated that small phytoplankton groups were more prominent on the Namibian shelf in September 2014 than in May 2014, particularly the prasinophytes, haptophytes and Synechococcus (Figures 6-9). Colder, lower salinity, nutrient sufficient water prevailed in September 2014 that was characterized as being in the first stage of newly upwelled water. Under these environmental conditions, it might be expected that diatoms would dominate as observed by Barlow (1982b) and Brown and Hutchings (1987) in the southern Benguela. However, these early studies did not evaluate the contribution of small phytoplankton cells as has been done for the northern Benguela by Hansen et al. (2014). CHEMTAX showed that although diatoms accounted for a greater proportion of the biomass on the $20^{\circ} \mathrm{S}$ transect and at the ZZ inshore stations in September 2014, this was not the case for the $23^{\circ} \mathrm{S}$ transect and the ZZ offshore stations (Figures 7 and 9). High phytoplankton biomass was confined much closer to the coast in September 2014 and there were patches of elevated chlorophyll $a$ in the vicinity of $20^{\circ} S$ (Figure 1d). But TChla was lower on the $23^{\circ} \mathrm{S}$ transect and at the offshore ZZ stations (Figures $1 \mathrm{~d}, 7$ and 9) and the flagellate groups were more dominant. The upper mixed layer was deeper on the $23^{\circ} \mathrm{S}$ transect and at the offshore $\mathrm{ZZ}$ stations (Figures 3d, 4d, 5d), indicating stronger vertical mixing, driven by stronger wind conditions in September 2014 (Figure 2d). Diatoms tend to flourish and bloom when the upper mixed layer is shallow and the water column is more stratified during periods of lower wind stress and reduced Ekman transport as in May 2014 (Figures 2b, 3b, 4b, 5b), resulting in elevated phytoplankton biomass that can extend for a considerable distance offshore, as illustrated in Figure 1b.

Prominent contribution by small flagellates to phytoplankton biomass in upwelling systems is not unusual and could be considered a general feature. Crespo et al. (2011) estimated that nanoflagellates accounted for $62-80 \%$ of the integrated biomass in both coastal and oceanic domains off northwest Iberia during a spring upwelling event. A similar pattern has also been observed in the Humboldt upwelling system off northern Chile where Iriarte et al. (2000) observed that nano- and picophytoplankton contributed $80 \%$ to primary production and $63 \%$ to TChla in summer, and $67 \%$ to both in the winter. A 2 year temporal study at a coastal site in central Chile by Bottjer and Morales (2007) demonstrated that nanoflagellates were the dominant component of the phytoplankton community during all seasons, contributing up to $80 \%$ to the autotrophic biomass in the upper $50 \mathrm{~m}$ during both upwelling and downwelling periods. In comparison, the average proportion of flagellates (including Synechococcus) along the $20^{\circ} \mathrm{S}$ transect off Namibia increased from $13 \%$ in May to $28 \%$ in September 2014, while the average proportion on the $23^{\circ} \mathrm{S}$ transect was $27 \%$ in the May and $72 \%$ during the September cruise. The average proportion for the ZZ inshore stations increased from $23 \%$ in May to $42 \%$ in September 2014, with the average at the ZZ offshore stations being $16 \%$ and $74 \%$ in the May and September respectively. It appears therefore that small flagellates contribute substantially to phytoplankton biomass on the central shelf of Namibia, as reported for the other upwelling ecosystems.

Overall, there are important differences in physical, geochemical and biological processes between the upwelling ecosystems of the southern Pacific and southern Atlantic eastern ocean margins $\left(3^{\circ}-40^{\circ} \mathrm{S}\right)$ (Mackas et al. 2006). There is strong ENSO activity in the Pacific, while "Benguela Ninos" occur with decadal frequency in the Atlantic. In addition, strong coastal trapped waves are a feature in both ecosystems, although this occurs intra-seasonally in the Pacific. While hypoxia, oxygen minimum layers 
and denitrification are a feature of the Pacific margin, there is a mismatch of time scales between phyto-, zoo- and meroplankton in the Atlantic margin. Trophic efficiency is higher in the southeastern Pacific, leading to greater fish production, but in contrast fish yield is lower in the southeastern Atlantic (Mackas et al. 2006).

Previously, small flagellates were observed to be more dominant at the Namibian shelf edge and on the slope (Barlow et al. 2006) and it is hypothesized that these flagellates were entrained in the upwelled water that moved inshore and up the shelf towards the coast in September 2014. The water column was not sufficiently stratified at the time of sampling for diatoms to have proliferated, and therefore the small flagellates that had populated the water column were observed to be more dominant on the $23^{\circ} \mathrm{S}$ transect and at the offshore ZZ stations. Barange and Pillar (1992) proposed a conceptual model of cross-shelf circulation during active and quiescent phases of upwelling, and suggested that during active upwelling, shelf circulation is characterised by seaward transport of surface waters, but the flow at depth is onshore, following isopycnal surfaces. Such a transport mechanism would account for the mid-shelf observation of flagellate communities, which are more common in the offshore regions. With the stronger vertical mixing in September 2014, it is likely that flagellate communities were mixed down to a depth where they were entrained in the onshore flow. Evidence of this transport mechanism can be seen in the vertical salinity distribution along $23^{\circ} \mathrm{S}$, where higher salinity water occurring at the surface between 60 and 70 $\mathrm{nm}$ from the coast appears to be subducted and advected shoreward below the upper mixed layer (Figure 4).

The prominence of small flagellates in contemporary upwelling ecosystems raises questions about their future role in the marine food web. The food chain in the Benguela ecosystem has been considered to be relatively simple, with mesozooplankton grazing on larger diatoms and dinoflagellates, macrozooplankton grazing on phytoplankton and mesozooplankton, small pelagic fish (anchovies, sardines) consuming predominately zooplankton, and larger fish such as hake feeding on small fish (Jarre-Teichmann et al. 1998; Hutchings et al. 2009). Besides the observation in this study, nanoflagellates have also been observed to be prominent in the southern Benguela ecosystem, predominantly offshore on the continental slope, but also on the shelf together with diatoms (MitchellInnes and Winter 1987; Barlow et al. 2005; Lamont et al. 2014). This implies that microzooplankton grazing probably plays an important role in the food web, grazing on the nanoflagellates and in turn being grazed by the mesozooplankton (Jarre-Teichmann et al. 1998). Thus the food web in the Benguela ecosystem is probably more complex than previously thought since this microbial loop most likely plays an important role. If there is a decline in upwelling-favourable winds due to climate change (Bakun et al. 2010), then it is likely that offshore Ekman transport would decrease along the Namibian shelf, as well as along the west coast of South Africa, leading to less or no upwelling of nutrient-rich water into the euphotic zone, with a consequent low abundance of diatoms and the dominance of nano- and picophytoplankton. The overall phytoplankton production and biomass are then likely to be lower than contemporary levels and the microbial loop would then become a key component of the food web. Mesoand macrozooplankton production and biomass could also decrease, with a resulting synergetic effect of upwelling changes and the role of the microbial loop over the biomass of small pelagic fish and larger demersal species such as hake.

Indeed, a substantial decrease in upwelling-favourable winds in the Northern Benguela has been observed in recent years (Lamont et al., 2017), and this corresponds to positive linear sea surface temperature trends suggestive of warming (Jarre et al., 2015). However, the impact of this longer-term reduction in upwelling and warming of surface waters has not yet been clearly discerned as satellite records of surface chlorophyll $a$ show a seemingly contradictory trend, with higher values in recent years (Jarre et al., 2015), while zooplankton trends are in agreement with a warming scenario and show an overall decrease in abundance and a shift in dominance by smaller species (Verheye et al., 2016). Modifications in the food web structure will have important implications for the commercial fisheries of Namibia and South Africa, and therefore current ecosystem- and fisheries-based management in each country needs to be reviewed 
and adjusted accordingly in consideration of the possible changes in water properties and plankton interactions.

Acknowledgements - We sincerely thank the officers and crew of the RV Mirabilis for their skilled cooperation and assistance during the cruise; technical staff of the Environmental sub-division at NatMIRC for shipboard and laboratory support; R Roman for nutrient analysis; the South African National Research Foundation and the National Commission on Research, Science and Technology of Namibia for funding support.

\section{References}

Anabalón V, Morales C, González H, Menschel E, Schneider W, Hormazabal S, Valencia L, Escribano R. 2016. Micro-phytoplankton community structure in the coastal upwelling zone off Concepción (central Chile): Annual and inter-annual fluctuations in a highly dynamic environment. Progress in Oceanography 149: 174-188.

Andersen P, Throndsen J. 2004. Estimating cell numbers. In: Hallegraeff G, Anderson D, Cembella A (eds), Manual on Harmful Marine Microalgae. UNESCO. pp. 99-129.

Bakun A, Field D, Redondo-Rodriguez A, Weeks S. 2010. Greenhouse gas, upwelling-favorable winds, and the future of coastal ocean upwelling ecosystems. Global Change Biology 16: 1213-1228.

Barange M, Pillar S. 1992. Cross-shelf circulation, zonation and maintenance mechanisms of Nyctiphanes capensis and Euphausia hanseni (Euphausiacea) in the northern Benguela upwelling system. Continental Shelf Research 12: 1027-1042.

Barlow R. 1982a. Phytoplankton ecology in the Southern Benguela current. I. Biochemical composition. Journal of Experimental Marine Biology and Ecology 63: 209-227.

Barlow R. 1982b. Phytoplankton ecology in the Southern Benguela Current. III.Dynamics of a bloom. Journal of Experimental Marine Biology and Ecology 63: 239-248.

Barlow R, Aiken J, Sessions H, Lavender S, Mantel J. 2001. Phytoplankton pigment, absorption and ocean colour characteristics in the southern Benguela ecosystem. South African Journal of Science 97: 230-238.

Barlow R, Louw D, Balarin M, Alheit J. 2006. Pigment signatures of phytoplankton composition in the northern Benguela ecosystem during spring. African Journal of Marine Science 28: 479-491.

Barlow R, Sessions H, Balarin M, Weeks S, Whittle C, Hutchings L. 2005. Seasonal variation in phytoplankton in the southern Benguela: pigment indices and ocean colour. African Journal of Marine Science 27: 275-287.

Bottjer D. Morales C. 2007. Nanoplanktonic assemblages in the upwelling area off Concepcion $\left(\sim 36^{\circ} \mathrm{S}\right)$, central Chile: Abundance, biomass, and grazing potential during the annual cycle. Progress in Oceanography 75: 415-434.

Brown P, Hutchings L. 1987. The development and decline of phytoplankton blooms in the southern Benguela upwelling system. 1. Drogue movements, hydrography and bloom development. In: Payne A, Gulland J, Brink K (eds), The Benguela and Comparable Ecosystems. South African Journal of Marine Science 5: 357-391. 
Crespo B, Espinoza-Gonzalez O, Teixeira I, Castro C, Figueiras F. 2011. Possible mixotrophy of pigmented nanoflagellates: Microbial plankton biomass, primary production and phytoplankton growth in the NW Iberian upwelling in spring. Estuarine, Coastal and Shelf Science 94: 172-181.

Du X, Peterson W, O’Higgins L. 2015. Interannual variations in phytoplankton community structure in the northern California Current during the upwelling seasons of 2001-2010. Marine Ecology Progress Series 519: 75-87.

Estrada M, Marrasé C. 1987. Phytoplankton biomass and productivity off the Namibian coast. In: Payne A, Gulland J, Brink K (eds), The Benguela and Comparable Ecosystems. South African Journal of Marine Science 5: 347-356.

Finney B, Alheit J, Erneis K, Field D, Gutierrez D, Struck U. 2010. Paleoecological studies on variability in marine fish populations: a longterm perspective on the impacts of climatic change on marine ecosystems. Journal of Marine Systems 79: 316-326.

Fishwick J, Aiken J, Barlow R, Sessions H, Bernard S, Ras J. 2006. Functional relationships and biooptical properties derived from phytoplankton pigments, optical and photosynthetic parameters; a case study of the Benguela ecosystem. Journal of the Marine Biological Association of the United Kingdom 86: $1267-1280$.

Hansen A, Ohde T, Wasmund N. 2014. Succession of micro- and nanoplankton groups in ageing upwelled waters off Namibia. Journal of Marine Systems 140: 130-137.

Henderiks J, Winter A, Elbrächter M, Feistel R, van der Plas A, Nausch G, Barlow R. 2012. Environmental controls on Emiliania huxleyi morphotypes in the Benguela coastal upwelling system (SE Atlantic). Marine Ecology Progress Series 448: 51-66.

Higgins H, Wright S, Schluter L. 2011. Quantitative interpretation of chemotaxonomic pigment data. In: Roy S, Llewellyn C, Egeland E, Johnsen G (eds), Phytoplankton pigments: characterization, chemotaxonomy and applications in oceanography. Cambridge: Cambridge University Press. pp 257313.

Hutchings L, van der Lingen C, Shannon L, Crawford R, Verheye H, Bartholomae C, van der Plas A, Louw D, Kreiner A, Ostrowski M, Fidel Q, Barlow R, Lamont T, Coetzee J, Shillington F, Veitch J, Currie J, Monteiro P, 2009. The Benguela Current: an ecosystem of four components. Progress in Oceanography 83: 15-32.

Iriarte J, Pizarro G, Troncoso V, Sobarzo M. 2000. Primary production and biomass of size-fractionated phytoplankton off Antofagasta, Chile $\left(23-24^{\circ} \mathrm{S}\right)$ during pre-El Nino and El Nino 1997. Journal of Marine Systems 26: 37-51.

Jarre A, Hutchings L, Kirkman S, Kreiner A, Tchipalanga P, Kainge P, Uanivi U, van der Plas A, Blamey L, Coetzee J, Lamont T, Samaai T, Verheye H, Yemane D, Axelsen B, Ostrowski M, Stenevik E, Loeng H. 2015. Synthesis: climate effects on biodiversity, abundance and distribution of marine organisms in the Benguela. Fisheries Oceanography 24 (S1): 122-149.

Jarre-Teichmann A, Shannon L, Moloney C, Wickens P. 1998. Comparing trophic flows in the southern Benuela to those in other upwelling ecosystems. South African Journal of Marine Science 19: 391-414.

Jeffrey S, Hallegraeff G. 1987. Chlorophyllase distribution in ten classes of phytoplankton : a problem for chlorophyll analysis. Marine Ecology Progress Series 35: 293-304. 
Jeffrey S, Wright S, Zapata M. 2011. Microalgal classes and their signature pigments. In: Roy S, Llewellyn C, Egeland E, Johnsen G (eds), Phytoplankton pigments: characterization, chemotaxonomy and applications in oceanography. Cambridge: Cambridge University Press. pp 3-77.

Kollmer W. 1962. The annual cycle of phytoplankton in the waters off Walvis Bay 1958. Investigational Report No. 4. South West Africa: Marine Research Laboratory. 44 pp.

Kollmer W. 1963. The pilchard of South West Africa. Monthly recordings of phytoplankton species in the area off Walvis Bay during 1959 and 1960. Investigational Report No. 8. South West Africa: Marine Research Laboratory. pp. 35-78.

Kruger I. 1980. A checklist of South West African marine phytoplankton, with some phytogeographical relations. Fisheries Bulletin of South Africa 13: 31-40.

Lamont T, Barlow R, Kyewalyanga M. 2014. Physical drivers of phytoplankton production in the southern Benguela upwelling system. Deep-Sea Research I 90: 1-16.

Lamont T, García-Reyes M, Bograd SJ, van der Lingen CD, Sydeman WJ. 2017. Upwelling indices for comparative ecosystem studies: Variability in the Benguela Upwelling System. Journal of Marine Systems (in press, http://dx.doi.org/10.1016/j.jmarsys.2017.05.007).

Lachkar Z, Gruber N. 2012. A comparative study of biological production in eastern boundary upwelling systems using an artificial neural network. Biogeosciences 9: 293-308.

Large W, Pond S. 1981. Open ocean momentum flux measurements in moderate to strong winds. Journal of Physical Oceanography 11: 324-336.

Louw D, Doucette G, Voges E. 2017. Annual patterns, distribution and long-term trends of Pseudonitzschia species in the northern Benguela upwelling system. Journal of Plankton Research 39: 35-47.

Louw D, van der Plas A, Mohrholz V, Wasmund N, Junker T, Eggert A. 2016. Seasonal and inter-annual phytoplankton dynamics and forcing mechanisms in the northern Benguela upwelling system. Journal of Marine Systems 157: 124-134.

Mackas D, Strub P, Thomas A, Montecino V. 2006. Eastern ocean boundaries pan-regional overview. In: Robinson A, Brink K (eds), The sea. The global coastal ocean: interdisciplinary regional studies and syntheses. Vol 14, part A. Cambridge MA: Harvard University Press. pp 21-59.

Mackey M, Mackey D, Higgins H, Wright S. 1996. CHEMTAX - a program for estimating class abundances from chemical markers: application to HPLC measurements of phytoplankton. Marine Ecology Progress Series 144: 265-283.

Mitchell-Innes B, Winter D. 1987. Coccolithophores: a major phytoplankton component in mature upwelled waters off the Cape Peninsula, South Africa in March, 1983. Marine Biology 95: 25-30.

Mostert S. 1983. Procedures used in South Africa for the automatic photometric determination of micronutrients in seawater. South African Journal of Marine Science 1: 189-198.

NASA Goddard Space Flight Center, Ocean Ecology Laboratory, Ocean Biology Processing Group (OBGP). 2018. Moderate-resolution Imaging Spectroradiometer (MODIS) Aqua Chlorophyll Data; 2018 Reprocessing. NASA OB.DAAC, Greenbelt, MB, USA (Accessed on 07/03/2018), doi: 10.5067/AQUA/MODIS/L3M/CHL/2018. 
Nelson G, Hutchings L. 1983. The Benguela upwelling area. Progress in Oceanography 12: 333-356.

Shannon L, Nelson G. 1996. The Benguela: large scale features and processes and system variability. In: Wefer G, Berger W, Siedler G, Webb D (eds), The South Atlantic: present and past circulation. Berlin: Springer. pp 163-210.

Thomson R, Fine I. 2003. Estimating mixed layer depth from oceanic profile data. Journal of Atmospheric and Oceanic Technology 20: 319-329.

Throndsen J. 1978. Preservation and storage. In: Sournia A (ed), Phytoplankton Manual. UNESCO Monographs on Oceanographic Methodology. pp 337.

Trenberth K, Large W, Olson J. 1990. The mean annual cycle in global ocean wind stress. Journal of Physical Oceanography 20:1742-1760.

Utermöhl H. 1958. Zur Vervollkommnung der quantitativen Phytoplankton-Methodik. Mitteilungen der Internationalen Vereiniung für Limnologie 9: 1-38.

Van Heukelem L, Hooker S. 2011. The importance of a quality assurance plan for method validation and minimizing uncertainties in the HPLC analysis of phytoplankton pigments. In: Roy S, Llewellyn C, Egeland E, Johnsen G (eds), Phytoplankton pigments: characterization, chemotaxonomy and applications in oceanography. Cambridge: Cambridge University Press. pp 195-242.

Verheye H, Lamont T, Huggett J, Kreiner A, Hampton I. 2016. Plankton productivity of the Benguela Current Large Marine Ecosystem (BCLME). Environmental Development 17: 75-92.

Wasmund N, Nausch G, Hansen A. 2014. Phytoplankton succession in an isolated upwelled Benguela water body in relation to different initial nutrient conditions. Journal of Marine Systems 140: 163-174.

Wright S, Ishikawa A, Marchant H, Davidson A, van den Enden R, Nash G. 2009. Composition and significance of picophytoplankton in Antarctic waters. Polar Biology 32: 797-808.

Zapata M, Rodríguez F, Garrido J. 2000. Separation of chlorophylls and carotenoids from marine phytoplankton: a new HPLC method using a reversed phase C8 column and pyridine containing mobile phases. Marine Ecology Progress Series 195: 29-45. 
Table 1

Pigment:chlorophyll $a$ starting and output ratios for the CHEMTAX analysis of HPLC pigments. Starting ratios derived from Higgins et al. (2011). Chla-chlorophyll $a$; Chlb-chlorophyll $b$; MgDVP-Mg-2,4-dininyl pheoporphyrin $a_{5}$ monomethyl ester; Chlc1-chlorophyll $c_{1}$; Chlc2-chlorophyll $c_{2}$; Chlc3-chlorophyll $c_{3}$; Per-peridinin; But-19'-butanoyloxyfucoxanthin; Fucfucoxanthin; Neo-neoxanthin; Viol-violaxanthin; Pras-prasinoxanthin; Hex-19'-hexanoyloxyfucoxanthin; Allo-alloxanthin; Zea-zeaxanthin; Anth-antheraxanthin; Asta-astaxanthin; Lutlutein; Chlc2-MGDG1-chlorophyll $c_{2}$-monogalactosyldiacylglyceride ester [18:4/14:0]; Chlc2-MGDG2-chlorophyll $c_{2}$-monogalactosyldiacylglyceride ester [14:0/14:0].

\begin{tabular}{|c|c|c|c|c|c|c|c|c|c|c|c|c|c|c|c|c|c|c|c|c|}
\hline Group & Chla & Chlb & $\begin{array}{c}\mathrm{Mg} \\
\mathrm{DVP}\end{array}$ & Chlc1 & Chlc2 & Chlc3 & Per & But & Fuc & $\mathrm{Neo}$ & Viol & Pras & Hex & Allo & Zea & Anth & Asta & Lut & $\begin{array}{c}\text { Chlc2- } \\
\text { MG } \\
\text { DG1 } \\
\end{array}$ & $\begin{array}{c}\text { Chlc2- } \\
\text { MG } \\
\text { DG2 } \\
\end{array}$ \\
\hline \multicolumn{21}{|l|}{ Starting Ratios } \\
\hline Diatoms-1 & 1 & 0 & 0 & 0.087 & 0.18 & 0 & 0 & 0 & 0.775 & 0 & 0 & 0 & 0 & 0 & 0 & 0 & 0 & 0 & 0 & 0 \\
\hline Dinoflagellates & 1 & 0 & 0.006 & 0 & 0.22 & 0 & 0.56 & 0 & 0 & 0 & 0 & 0 & 0 & 0 & 0 & 0 & 0 & 0 & 0 & 0 \\
\hline Cryptophytes & 1 & 0 & 0 & 0 & 0.2 & 0 & 0 & 0 & 0 & 0 & 0 & 0 & 0 & 0.38 & 0 & 0 & 0 & 0 & 0 & 0 \\
\hline Pelagophytes & 1 & 0 & 0 & 0.01 & 0.275 & 0.23 & 0 & 0.66 & 0.78 & 0 & 0 & 0 & 0 & 0 & 0 & 0 & 0 & 0 & 0 & 0 \\
\hline Haptophytes & 1 & 0 & 0.009 & 0 & 0.21 & 0.18 & 0 & 0.04 & 0.31 & 0 & 0 & 0 & 0.47 & 0 & 0 & 0 & 0 & 0 & 0.09 & 0.103 \\
\hline Prasinophytes-3 & 1 & 0.73 & 0.062 & 0 & 0 & 0 & 0 & 0 & 0 & 0.063 & 0.054 & 0.25 & 0 & 0 & 0.058 & 0.021 & 0 & 0.021 & 0 & 0 \\
\hline Chlorophytes & 1 & 0.32 & 0 & 0 & 0 & 0 & 0 & 0 & 0 & 0.066 & 0.049 & 0 & 0 & 0 & 0.032 & 0.014 & 0.012 & 0.17 & 0 & 0 \\
\hline $\begin{array}{l}\text { Cyanobacteria } \\
\text { (Synechococcus) }\end{array}$ & 1 & 0 & 0 & 0 & 0 & 0 & 0 & 0 & 0 & 0 & 0 & 0 & 0 & 0 & 0.64 & 0 & 0 & 0 & 0 & 0 \\
\hline \multicolumn{21}{|l|}{ May 2014} \\
\hline Diatoms-1 & 1 & 0 & 0 & 0.135 & 0.148 & 0 & 0 & 0 & 0.761 & 0 & 0 & 0 & 0 & 0 & 0 & 0 & 0 & 0 & 0 & 0 \\
\hline Diatoms-2 & 1 & 0 & 0 & 0 & 0.222 & 0.133 & 0 & 0 & 0.482 & 0 & 0 & 0 & 0 & 0 & 0 & 0 & 0 & 0 & 0 & 0 \\
\hline Dinoflagellates & 1 & 0 & 0.005 & 0 & 0.212 & 0 & 0.776 & 0 & 0 & 0 & 0 & 0 & 0 & 0 & 0 & 0 & 0 & 0 & 0 & 0 \\
\hline Cryptophytes & 1 & 0 & 0 & 0 & 0.187 & 0 & 0 & 0 & 0 & 0 & 0 & 0 & 0 & 0.257 & 0 & 0 & 0 & 0 & 0 & 0 \\
\hline Pelagophytes & 1 & 0 & 0 & 0.008 & 0.236 & 0.241 & 0 & 0.840 & 0.759 & 0 & 0 & 0 & 0 & 0 & 0 & 0 & 0 & 0 & 0 & 0 \\
\hline Prasinophytes-1 & 1 & 0.427 & 0.008 & 0 & 0 & 0 & 0 & 0 & 0 & 0.060 & 0.153 & 0 & 0 & 0 & 0.018 & 0.023 & 0 & 0.055 & 0 & 0 \\
\hline Prasinophytes-3 & 1 & 0.980 & 0.082 & 0 & 0 & 0 & 0 & 0 & 0 & 0.060 & 0.069 & 0.120 & 0 & 0 & 0.076 & 0.026 & 0 & 0.017 & 0 & 0 \\
\hline Chlorophytes & 1 & 0 & 0 & 0 & 0 & 0 & 0 & 0 & 0 & 0 & 0 & 0 & 0 & 0 & 0 & 0 & 0 & 0 & 0 & 0 \\
\hline $\begin{array}{l}\text { Cyanobacteria } \\
\text { (Synechococcus) }\end{array}$ & 1 & 0 & 0 & 0 & 0 & 0 & 0 & 0 & 0 & 0 & 0 & 0 & 0 & 0 & 0.832 & 0 & 0 & 0 & 0 & 0 \\
\hline \multicolumn{21}{|l|}{ September 2014} \\
\hline Diatoms-1 & 1 & 0 & 0 & 0.088 & 0.101 & 0 & 0 & 0 & 0.513 & 0 & 0 & 0 & 0 & 0 & 0 & 0 & 0 & 0 & 0 & 0 \\
\hline Diatoms-2 & 1 & 0 & 0 & 0 & 0.258 & 0.109 & 0 & 0 & 0.851 & 0 & 0 & 0 & 0 & 0 & 0 & 0 & 0 & 0 & 0 & 0 \\
\hline Dinoflagellates & 1 & 0 & 0.008 & 0 & 0.154 & 0 & 0.742 & 0 & 0 & 0 & 0 & 0 & 0 & 0 & 0 & 0 & 0 & 0 & 0 & 0 \\
\hline Cryptophytes & 1 & 0 & 0 & 0 & 0.168 & 0 & 0 & 0 & 0 & 0 & 0 & 0 & 0 & 0.368 & 0 & 0 & 0 & 0 & 0 & 0 \\
\hline Pelagophytes & 1 & 0 & 0 & 0.008 & 0.194 & 0.293 & 0 & 0.763 & 0.819 & 0 & 0 & 0 & 0 & 0 & 0 & 0 & 0 & 0 & 0 & 0 \\
\hline Haptophytes & 1 & 0 & 0.012 & 0 & 0.323 & 0.299 & 0 & 0.042 & 0.397 & 0 & 0 & 0 & 0.793 & 0 & 0 & 0 & 0 & 0 & 0.133 & 0.129 \\
\hline Prasinophytes-1 & 1 & 0.601 & 0.008 & 0 & 0 & 0 & 0 & 0 & 0 & 0.063 & 0.096 & 0 & 0 & 0 & 0.028 & 0.029 & 0 & 0.045 & 0 & 0 \\
\hline Prasinophytes-3 & 1 & 0.687 & 0.069 & 0 & 0 & 0 & 0 & 0 & 0 & 0.064 & 0.054 & 0.129 & 0 & 0 & 0.056 & 0.018 & 0 & 0.014 & 0 & 0 \\
\hline Chlorophytes & 1 & 0.315 & 0 & 0 & 0 & 0 & 0 & 0 & 0 & 0.088 & 0.046 & 0 & 0 & 0 & 0.042 & 0.019 & 0.015 & 0.215 & 0 & 0 \\
\hline $\begin{array}{l}\text { Cyanobacteria } \\
\text { (Synechococcus) }\end{array}$ & 1 & 0 & 0 & 0 & 0 & 0 & 0 & 0 & 0 & 0 & 0 & 0 & 0 & 0 & 0.642 & 0 & 0 & 0 & 0 & 0 \\
\hline
\end{tabular}


Table 2

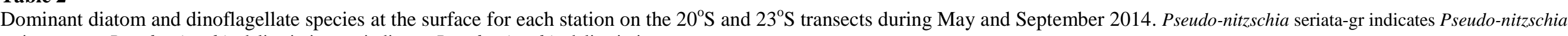
seriata-group. Pseudo-nitzschia delicatissima-gr indicates Pseudo-nitzschia delicatissima-group.

\begin{tabular}{|c|c|c|c|c|c|c|c|c|c|}
\hline May & Diatoms & Cells L $^{-1}$ & Dinoflagellates & Cells L $^{-1}$ & September & Diatoms & Cells L $^{-1}$ & Dinoflagellates & Cells L $^{-1}$ \\
\hline $20^{\circ} \mathrm{S}$ & Pseudo-nitzschia seriata-gr & $14.89 \times 10^{3}$ & Ceratium $\mathrm{spp}$ & $5.47 \times 10^{3}$ & $20^{\circ} \mathrm{S}$ & Thalassiosira gravida & $21.33 \times 10^{4}$ & Gyrodinium spp & $4.35 \times 10^{3}$ \\
\hline \multirow[t]{4}{*}{2} & Chaetoceros curvisetus & $11.45 \times 10^{3}$ & Prorocentrum micans & $4.58 \times 10^{3}$ & 2 & & & & \\
\hline & & & Unidentified dinoflagellates & $3.43 \times 10^{3}$ & & & & & \\
\hline & & & & & $20^{\circ} \mathrm{S}$ & Thalassiosira gravida & $84.45 \times 10^{4}$ & $\begin{array}{l}\text { Gymnodenium spp } \\
\text { Gyrodinium snn }\end{array}$ & $\begin{array}{l}7.33 \times 10^{3} \\
618 \times 10^{3}\end{array}$ \\
\hline & & & & & & & & $\begin{array}{l}\text { Gyroalnium spp } \\
\text { Protoperidinium spp }\end{array}$ & $5.38 \times 10^{3}$ \\
\hline $20^{\circ} \mathrm{S}$ & Chaetoceros curvisetus & $13.40 \times 10^{4}$ & Ceratium spp & $14.04 \times 10^{3}$ & $20^{\circ} \mathrm{S}$ & Thalassiosira gravida & $77.92 \times 10^{4}$ & Gyrodinium spp & $28.98 \times 10^{3}$ \\
\hline 10 & Pseudo-nitzschia seriata-gr & $66.44 \times 10^{3}$ & & & 10 & Thalassiosira rotula & $28.73 \times 10^{4}$ & $\begin{array}{l}\text { Scrippsiella trochoidea } \\
\text { Noctiluca scintillans }\end{array}$ & $\begin{array}{l}10.88 \times 10^{3} \\
10.31 \times 10^{3}\end{array}$ \\
\hline \multirow{2}{*}{$\begin{array}{c}20^{\circ} \mathrm{S} \\
20\end{array}$} & Chaetoceros debilis & $24.51 \times 10^{4}$ & Ceratium spp & $42.92 \times 10^{3}$ & $20^{\circ} \mathrm{S}$ & Thalassiosira rotula & $82.71 \times 10^{3}$ & Unidentified dinoflagellates & $4.12 \times 10^{3}$ \\
\hline & $\begin{array}{l}\text { Pseudo-nitzschia seriata-gr } \\
\text { Chaetoceros curvisetus }\end{array}$ & $\begin{array}{l}24.40 \times 10^{4} \\
10.65 \times 10^{4}\end{array}$ & & & 20 & Leptocylindrus danicus & $60.94 \times 10^{3}$ & & \\
\hline $20^{\circ} \mathrm{S}$ & Pseudo-nitzschia seriata-gr & $2.67 \times 10^{6}$ & Unidentified dinoflagellates & $9.16 \times 10^{3}$ & $20^{\circ} \mathrm{S}$ & Leptocylindrus danicus & $32.21 \times 10^{4}$ & Ceratium furca & $10.66 \times 10^{3}$ \\
\hline \multirow[t]{2}{*}{30} & Chaetoceros curvisetus & $2.08 \times 10^{6}$ & & & 30 & Thalassiosira gravida & $28.73 \times 10^{4}$ & Unidentified dinoflagellates & $6.53 \times 10^{3}$ \\
\hline & Chaetoceros debilis & $1.39 \times 10^{6}$ & & & & Thalassiosira anguste-lineata & $27.64 \times 10^{4}$ & Dinophysis fortii & $6.30 \times 10^{3}$ \\
\hline $20^{\circ} \mathrm{S}$ & Thalassiosira gravida & $69.42 \times 10^{4}$ & Corythodinium tesselatus & $1.14 \times 10^{3}$ & $20^{\circ} \mathrm{S}$ & Pseudo-nitzschia seriata-gr & $76.18 \times 10^{3}$ & Unidentified dinoflagellates & $30.24 \times 10^{3}$ \\
\hline 40 & Bacteriastrum delicatulum & $35.17 \times 10^{4}$ & Gyrodinium spp & $1.14 \times 10^{3}$ & 40 & $\begin{array}{l}\text { Leptocylindrus danicus } \\
\text { Thalassiosira gravida }\end{array}$ & $\begin{array}{l}74.01 \times 10^{3} \\
39.18 \times 10^{3}\end{array}$ & Prorocentrum triestinum & $23.94 \times 10^{3}$ \\
\hline $20^{\circ} \mathrm{S}$ & Bacteriastrum delicatulum & $1.62 \times 10^{6}$ & Unidentified dinoflagellates & $8.02 \times 10^{3}$ & $20^{\circ} \mathrm{S}$ & Thalassiosira gravida & $10.40 \times 10^{4}$ & Unidentified dinoflagellates & $4.12 \times 10^{3}$ \\
\hline 50 & Pseudo-nitzschia seriata-gr & $88.44 \times 10^{4}$ & Protoperidinium pallidum & $3.43 \times 10^{3}$ & 50 & Leptocylindrus danicus & $85.57 \times 10^{3}$ & & \\
\hline $20^{\circ} \mathrm{S}$ & Bacteriastrum hyalinum & $97.15 \times 10^{4}$ & Protoperidinium spp & $2.29 \times 10^{3}$ & $20^{\circ} \mathrm{S}$ & Thalassiosira gravida & $78.36 \times 10^{3}$ & Scrippsiella trochoidea & $9.28 \times 10^{3}$ \\
\hline \multirow{2}{*}{60} & & & & & 60 & Chaetoceros decipiens & $53.61 \times 10^{3}$ & Dinophysis acuminata & $6.18 \times 10^{3}$ \\
\hline & & & & & & Chaetoceros didymus & $53.61 \times 10^{3}$ & Unidentified dinoflagellates & $6.18 \times 10^{3}$ \\
\hline $20^{\circ} \mathrm{S}$ & Bacteriastrum delicatulum & $2.16 \times 10^{6}$ & Unidentified dinoflagellates & $2.29 \times 10^{3}$ & $20^{\circ} \mathrm{S}$ & Thalassiosira gravida & $14.43 \times 10^{3}$ & Unidentified dinoflagellates & $11.34 \times 10^{3}$ \\
\hline 70 & & & & & 70 & & & Prorocentrum triestinum & $8.25 \times 10^{3}$ \\
\hline \multirow{2}{*}{$\begin{array}{c}23^{\circ} \mathrm{S} \\
2\end{array}$} & Cylindrotheca closterium & $36.66 \times 10^{4}$ & Naked dinoflagellates & $12.60 \times 10^{3}$ & $23^{\circ} \mathrm{S}$ & Skeletonema japonica & $20.62 \times 10^{3}$ & Prorocentrum triestinum & $1.14 \times 10^{3}$ \\
\hline & & & Prorocentrum micans & $5.72 \times 10^{3}$ & 2 & Navicula spp & $12.60 \times 10^{3}$ & & \\
\hline $23^{\circ} \mathrm{S}$ & Cylindrotheca closterium & $73.32 \times 10^{3}$ & Unidentified dinoflagellates & $10.31 \times 10^{3}$ & $23^{\circ} \mathrm{S}$ & Unidentified diatoms & $2.29 \times 10^{3}$ & Protoperidinium spp & $1.14 \times 10^{3}$ \\
\hline \multirow[t]{2}{*}{5} & Pseudo-nitzschia seriata-gr & $37.81 \times 10^{3}$ & Protoperidinium spp & $5.72 \times 10^{3}$ & 5 & & & & \\
\hline & Bacteriastrum hyalinum & $29.78 \times 10^{3}$ & & & & & & & \\
\hline $23^{\circ} \mathrm{S}$ & Pseudo-nitzschia seriata-gr & $82.48 \times 10^{3}$ & Naked dinoflagellates & $17.18 \times 10^{3}$ & $23^{\circ} \mathrm{S}$ & Pseudo-nitzschia delicatissima-gr & $3.43 \times 10^{3}$ & Unidentified dinoflagellates & $1.14 \times 10^{3}$ \\
\hline 10 & & & Unidentified dinoflagellates & $13.74 \times 10^{3}$ & 10 & Navicula spp & $2.29 \times 10^{3}$ & & \\
\hline $23^{\circ} \mathrm{S}$ & Pseudo-nitzschia seriata-gr & $12.48 \times 10^{4}$ & Unidentified dinoflagellates & $6.87 \times 10^{3}$ & $23^{\circ} \mathrm{S}$ & Chaetoceros curvisetus & $73.32 \times 10^{3}$ & Dinophysis fortii & $1.14 \times 10^{3}$ \\
\hline 20 & & & & & 20 & & & Protoperidinium spp & $1.14 \times 10^{3}$ \\
\hline $23^{\circ} \mathrm{S}$ & Pseudo-nitzschia seriata-gr & $12.71 \times 10^{4}$ & Unidentified dinoflagellates & $8.02 \times 10^{3}$ & $23^{\circ} \mathrm{S}$ & Chaetoceros constrictus & $6.87 \times 10^{3}$ & Scrippsiella trochoidea & $4.58 \times 10^{3}$ \\
\hline 30 & & & Ceratium spp & $3.37 \times 10^{3}$ & 30 & & & & \\
\hline $23^{\circ} \mathrm{S}$ & Pseudo-nitzschia seriata-gr & $3.83 \times 10^{6}$ & Naked dinoflagellates & $4.58 \times 10^{3}$ & $23^{\circ} \mathrm{S}$ & Chaetoceros curvisetus & $1.14 \times 10^{3}$ & Unidentified dinoflagellates & $2.29 \times 10^{3}$ \\
\hline 40 & & & Scrippsiella trochoidea & $3.43 \times 10^{3}$ & 40 & & & & \\
\hline $23^{\circ} \mathrm{S}$ & Rhizosolenia robusta & $1.05 \times 10^{3}$ & Unidentified dinoflagellates & $5.72 \times 10^{3}$ & $23^{\circ} \mathrm{S}$ & Chaetoceros convolutus & $14.89 \times 10^{3}$ & None & \\
\hline 50 & Cylindrotheca closterium & $1.14 \times 10^{3}$ & & & 50 & & & & \\
\hline
\end{tabular}




\begin{tabular}{|c|c|c|c|c|c|c|c|c|c|}
\hline $\begin{array}{c}23^{\circ} \mathrm{S} \\
60\end{array}$ & $\begin{array}{c}\text { Centric diatoms } \\
\text { Centric diatoms } \\
\text { Pseudo-nitzschia seriata-gr }\end{array}$ & $\begin{array}{l}1.14 \times 10^{3} \\
8.02 \times 10^{3} \\
5.72 \times 10^{3}\end{array}$ & $\begin{array}{l}\text { Scrippsiella trochoidea } \\
\text { Gyrodinium spp }\end{array}$ & $\begin{array}{l}13.74 \times 10^{3} \\
5.72 \times 10^{3}\end{array}$ & $\begin{array}{c}23^{\circ} \mathrm{S} \\
60\end{array}$ & $\begin{array}{l}\text { Pseudo-nitzschia delicatissima-gr } \\
\text { Chaetoceros atlanticus } \\
\text { Pseudo-nitzschia seriata-gr }\end{array}$ & $\begin{array}{l}32.07 \times 10^{3} \\
22.91 \times 10^{3} \\
20.62 \times 10^{3}\end{array}$ & Gyrodinium spp & $2.29 \times 10^{3}$ \\
\hline $\begin{array}{c}23^{\circ} \mathrm{S} \\
70\end{array}$ & Thalassiosira $\mathrm{sp}$ & $12.94 \times 10^{4}$ & Naked dinoflagellates & $5.72 \times 10^{3}$ & $\begin{array}{c}23^{\circ} \mathrm{S} \\
70\end{array}$ & Pseudo-nitzschia delicatissima-gr & $67.59 \times 10^{3}$ & $\begin{array}{l}\text { Unidentified dinoflagellates } \\
\text { Protoperidinium oblongum }\end{array}$ & $\begin{array}{l}3.43 \times 10^{3} \\
1.14 \times 10^{3}\end{array}$ \\
\hline
\end{tabular}


Figure 1. Monthly composites of MODIS Aqua Sea Surface Temperature for (a) May 2014 and (c) September 2014, and chlorophyll $a$ concentration for (b) May 2014 and (d) September 2014. Black dots and squares indicate positions of sampling stations on the $20^{\circ} \mathrm{S}$ and $23^{\circ} \mathrm{S}$ transects and the $\mathrm{ZZ}$ stations respectively. White areas indicate missing data due to cloud cover or fog. Abbreviations are WB-Walvis Bay, SW-Swakopmund, CC-Cape Cross, TC-Toscanini, TB-Terrace Bay. The images provide a larger "aerial view" geographic and hydrographic context for the two cruise periods.

Figure 2. Daily Eckman transport (dark grey) for 6-18 May 2014 at (a) $20^{\circ} \mathrm{S}$ and (b) $23^{\circ} \mathrm{S}$ and for $5-16$ September 2014 at (c) $20^{\circ} \mathrm{S}$ and (d) $23^{\circ} \mathrm{S}$. Light grey indicates the cruise periods for 9-15 May and 8-13 September 2014.

Figure 3. Temperature profiles on the $20^{\circ} \mathrm{S}$ transect for (a) May 2014 and (c) September 2014, and on the $23^{\circ} \mathrm{S}$ transect for (b) May 2014 and (d) September 2014. Horizontal black lines indicate the depth of the upper mixed layer $\left(Z_{m}\right)$. Vertical dotted lines indicate the depth of CTD profiles.

Figure 4. Salinity profiles on the $20^{\circ} \mathrm{S}$ transect for (a) May 2014 and (c) September 2014, and on the $23^{\circ} \mathrm{S}$ transect for (b) May 2014 and (d) September 2014. Horizontal black lines indicate the depth of the upper mixed layer $\left(\mathrm{Z}_{\mathrm{m}}\right)$. Vertical dotted lines indicate the depth of CTD profiles.

Figure 5. Temperature profiles on the ZZ inshore transect for (a) May 2014 and (c) September 2014, and on the ZZ offshore transect for (b) May 2014 and (d) September 2014. Horizontal black lines indicate the depth of the upper mixed layer $\left(Z_{m}\right)$. Vertical dotted lines indicate the depth of CTD profiles.

Figure 6. Surface pattern on the $20^{\circ} \mathrm{S}$ transect during May and September 2014 for (a, d) temperature and nutrients, (b, e) TChla, and (c, f) the proportion of each phytoplankton group contributing to TChla.

Figure 7. Surface pattern on the $23^{\circ} \mathrm{S}$ transect during May and September 2014 for (a, d) temperature and nutrients, (b, e) TChla, and (c, f) the proportion of each phytoplankton group contributing to TChla.

Figure 8. Surface pattern at the ZZ inshore stations during May and September 2014 for (a, d) temperature, (b, e) TChla, and (c, f) the proportion of each phytoplankton group contributing to TChla.

Figure 9. Surface pattern at the ZZ offshore stations during May and September 2014 for (a, d) temperature, (b, e) TChla, and (c, f) the proportion of each phytoplankton group contributing to TChla. 
Fig. 1

738

(a)
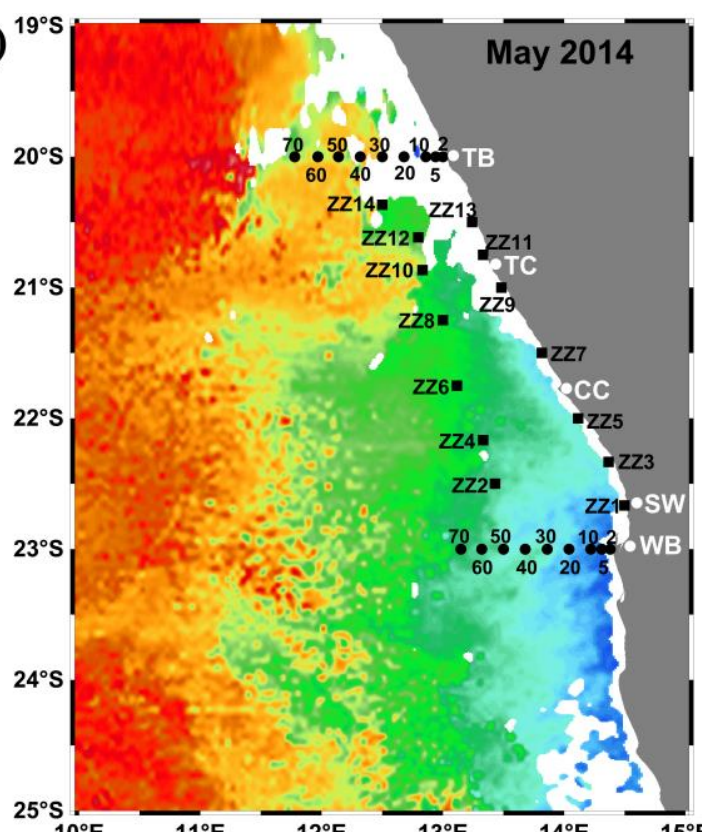

(b)
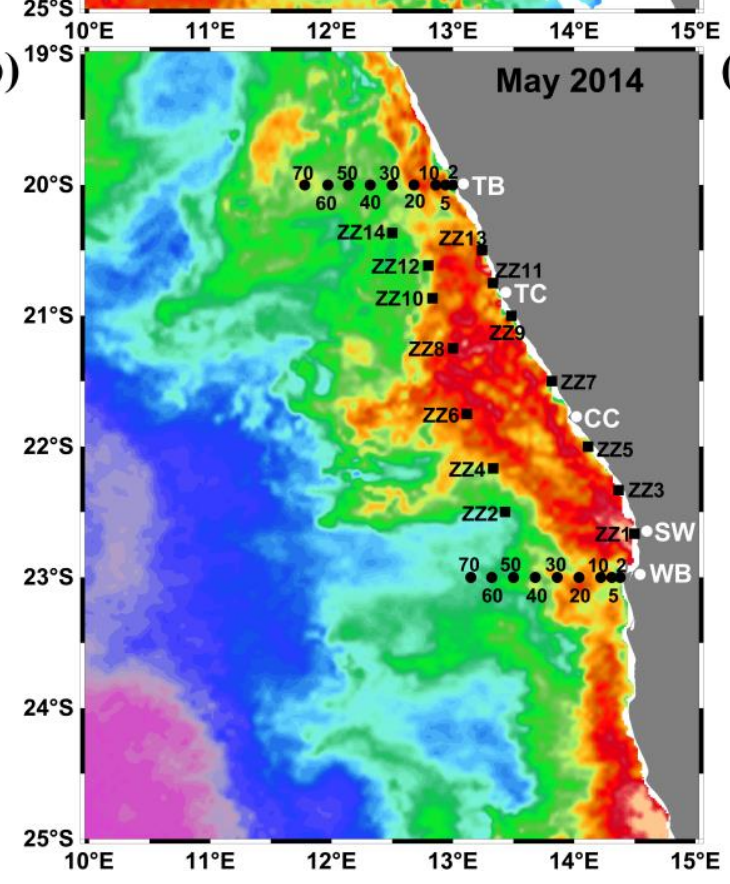

(c)

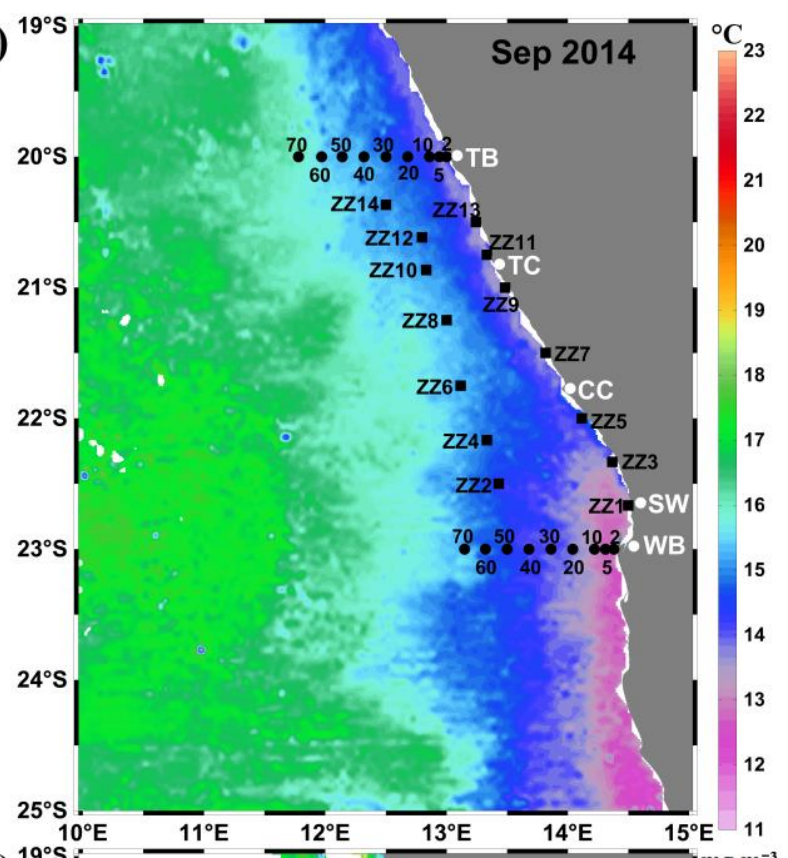

(d)

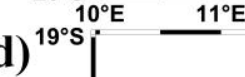

d) $19^{\circ}$

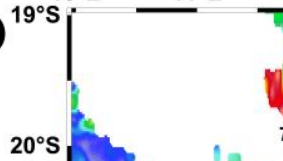

$14^{\circ} \mathrm{E}$
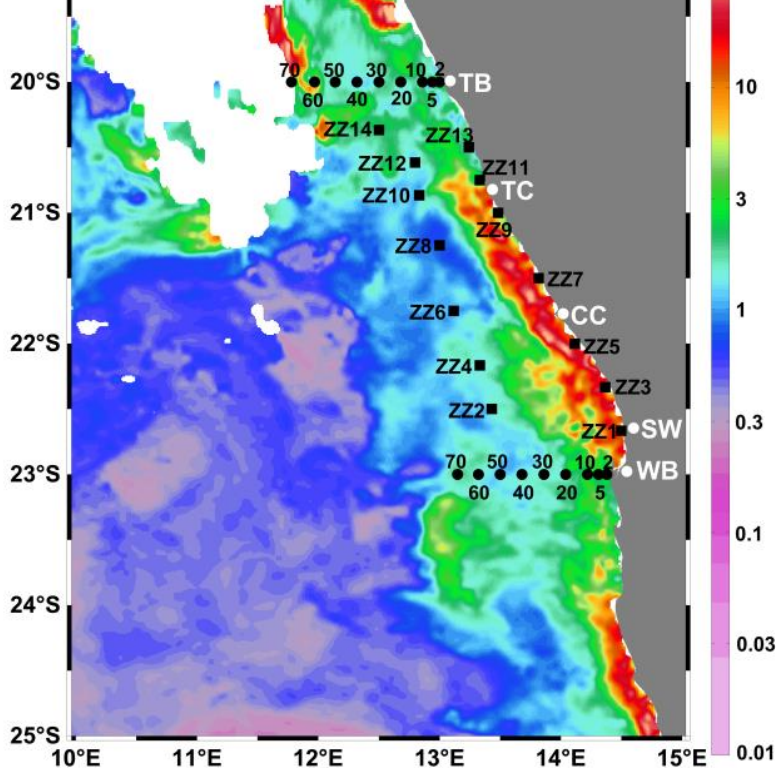
Fig. 2

757
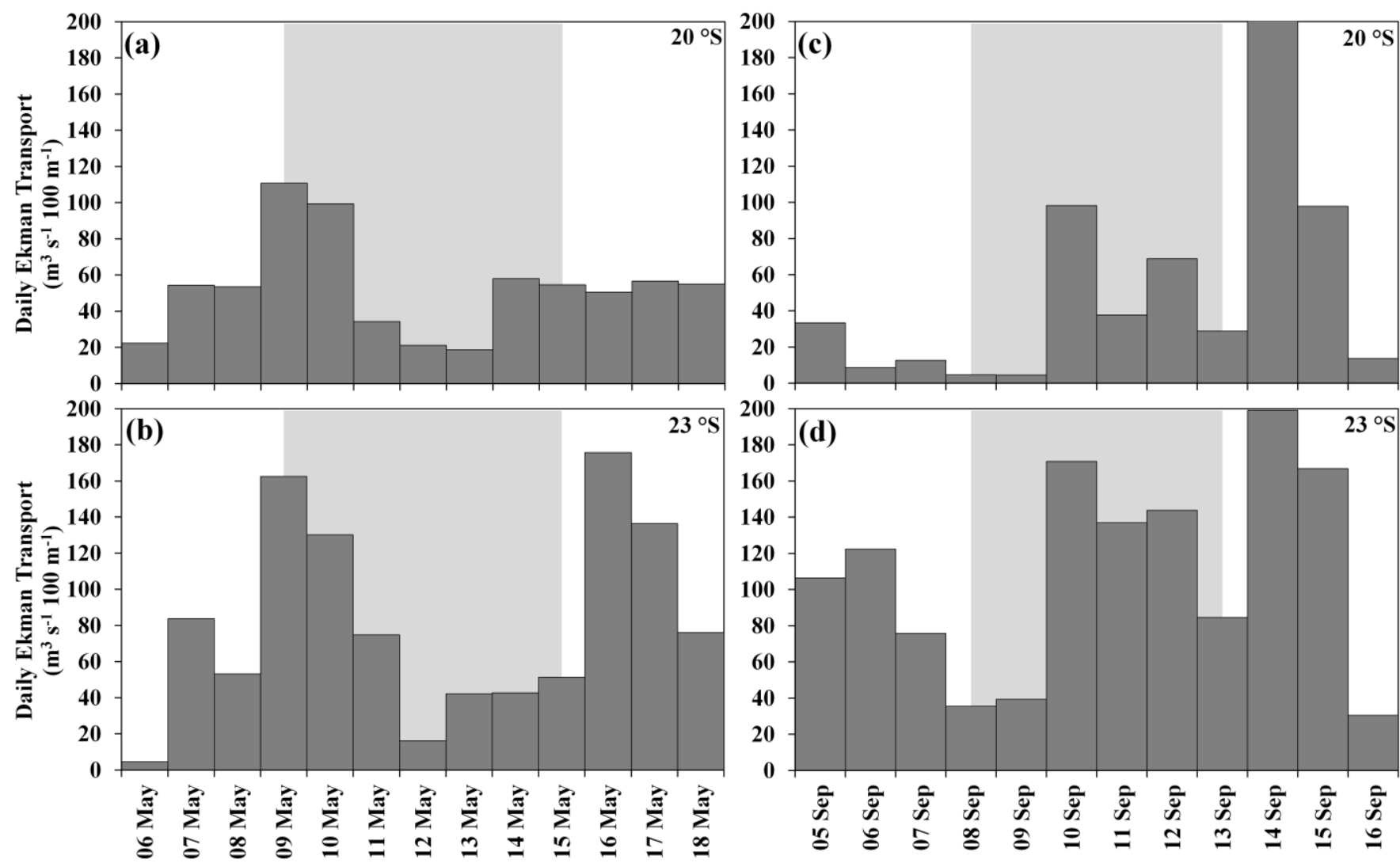

Fig. 3
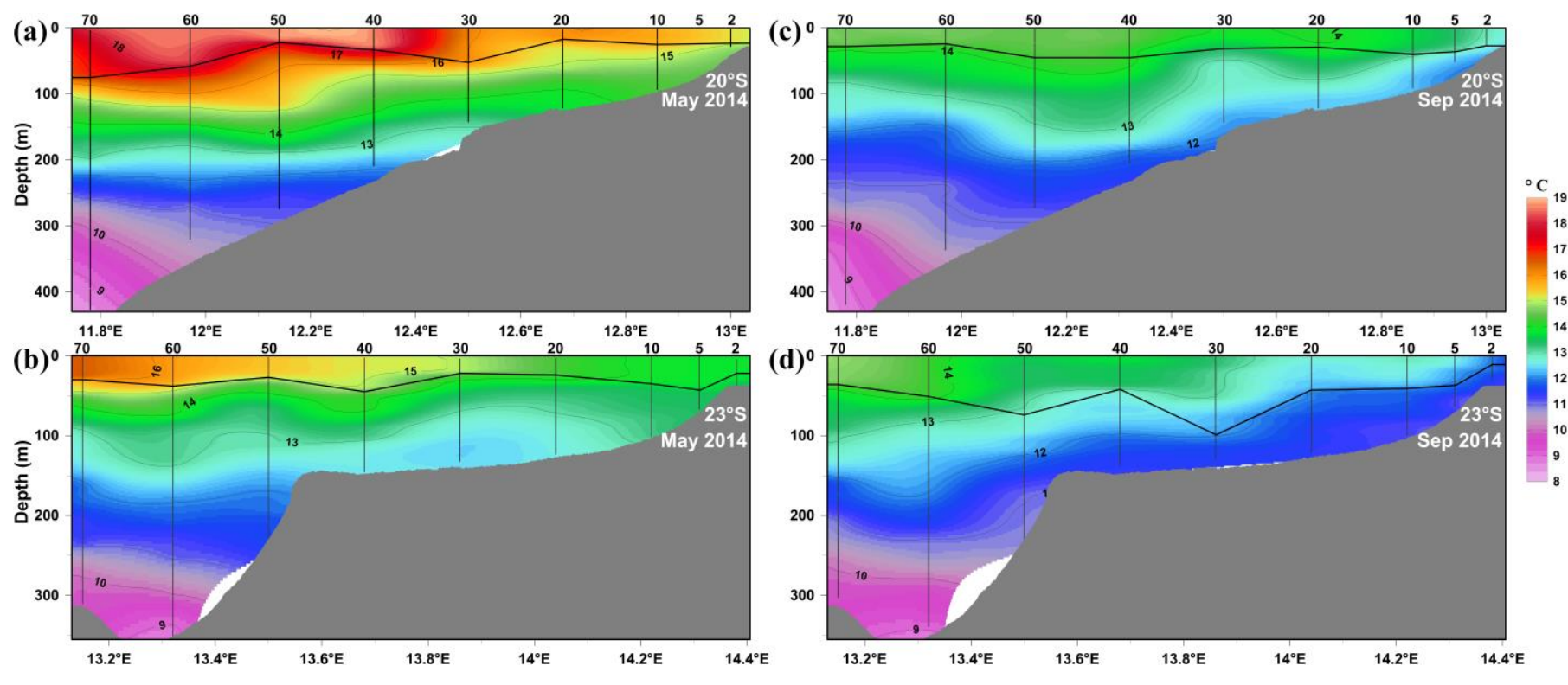
Fig. 4

774
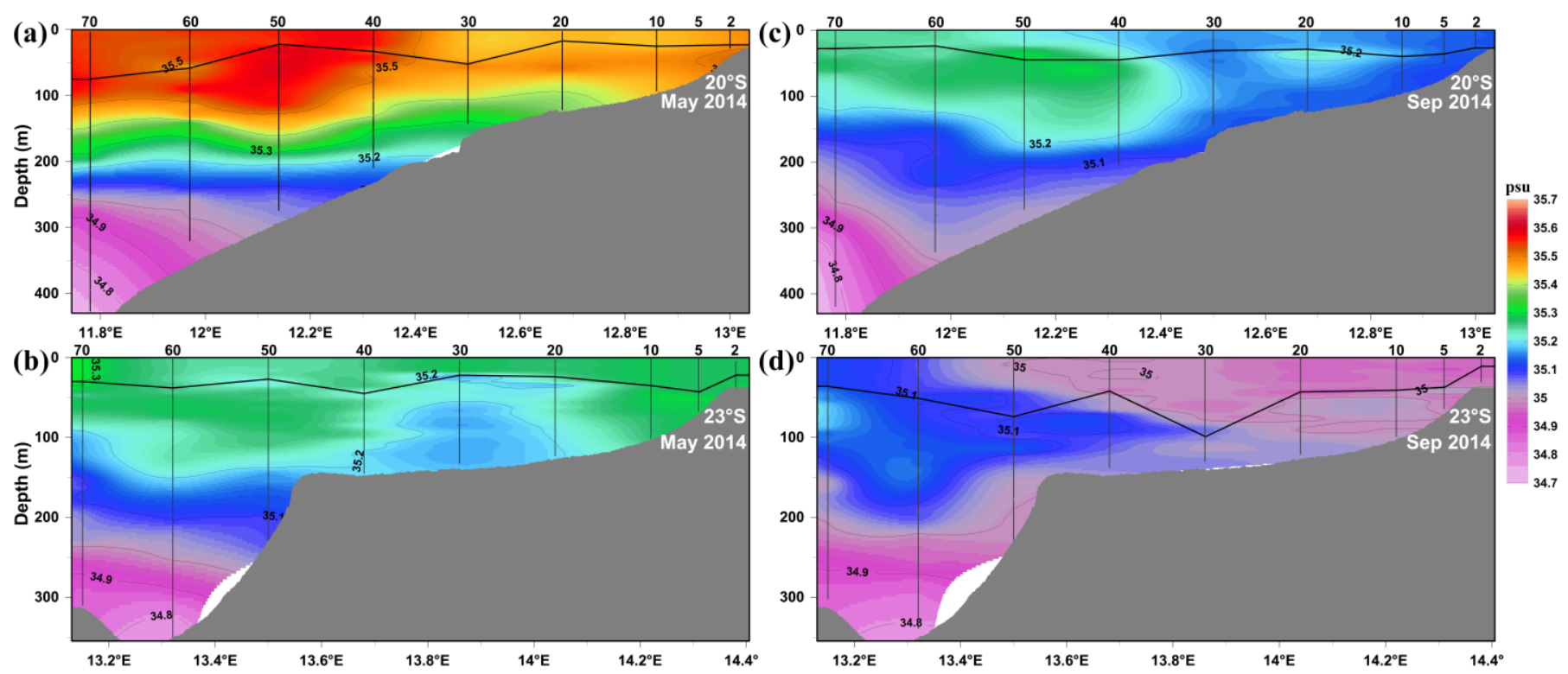

775

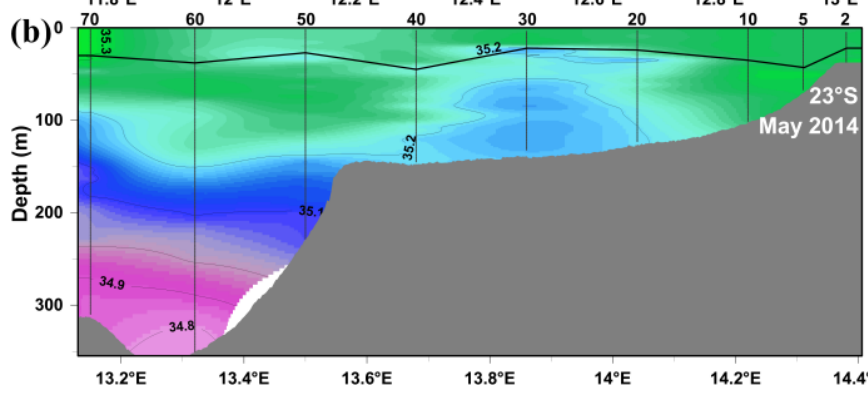

Fig. 5
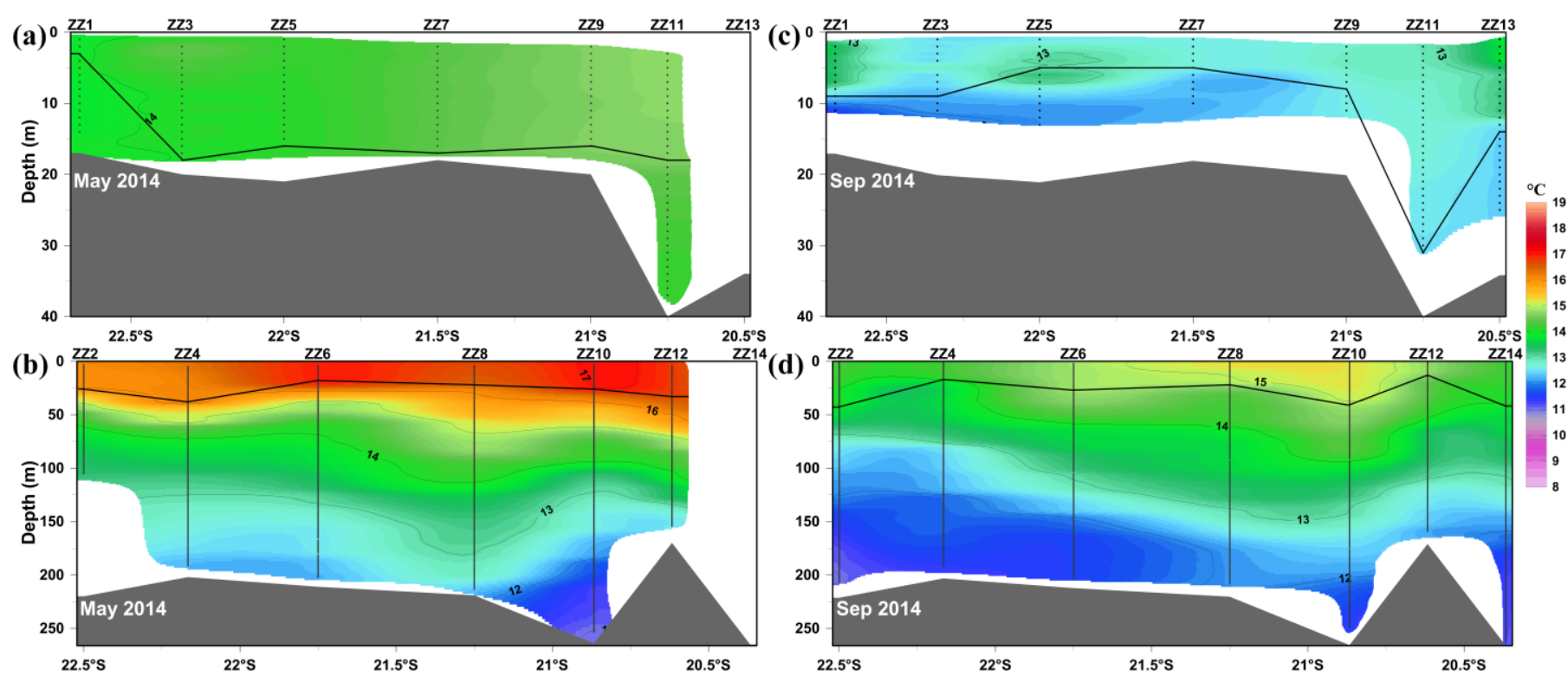
Fig. 6
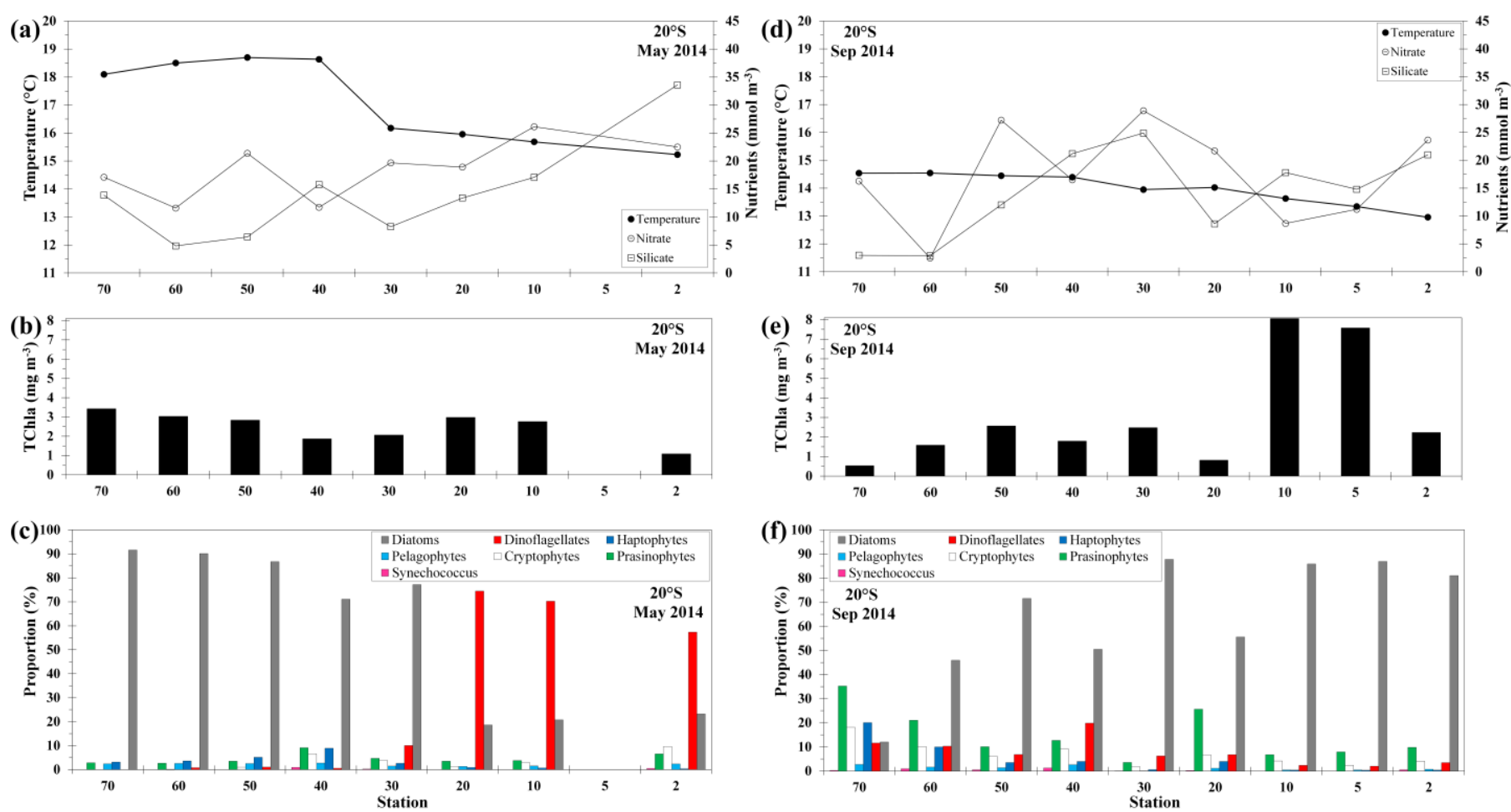

Fig. 7
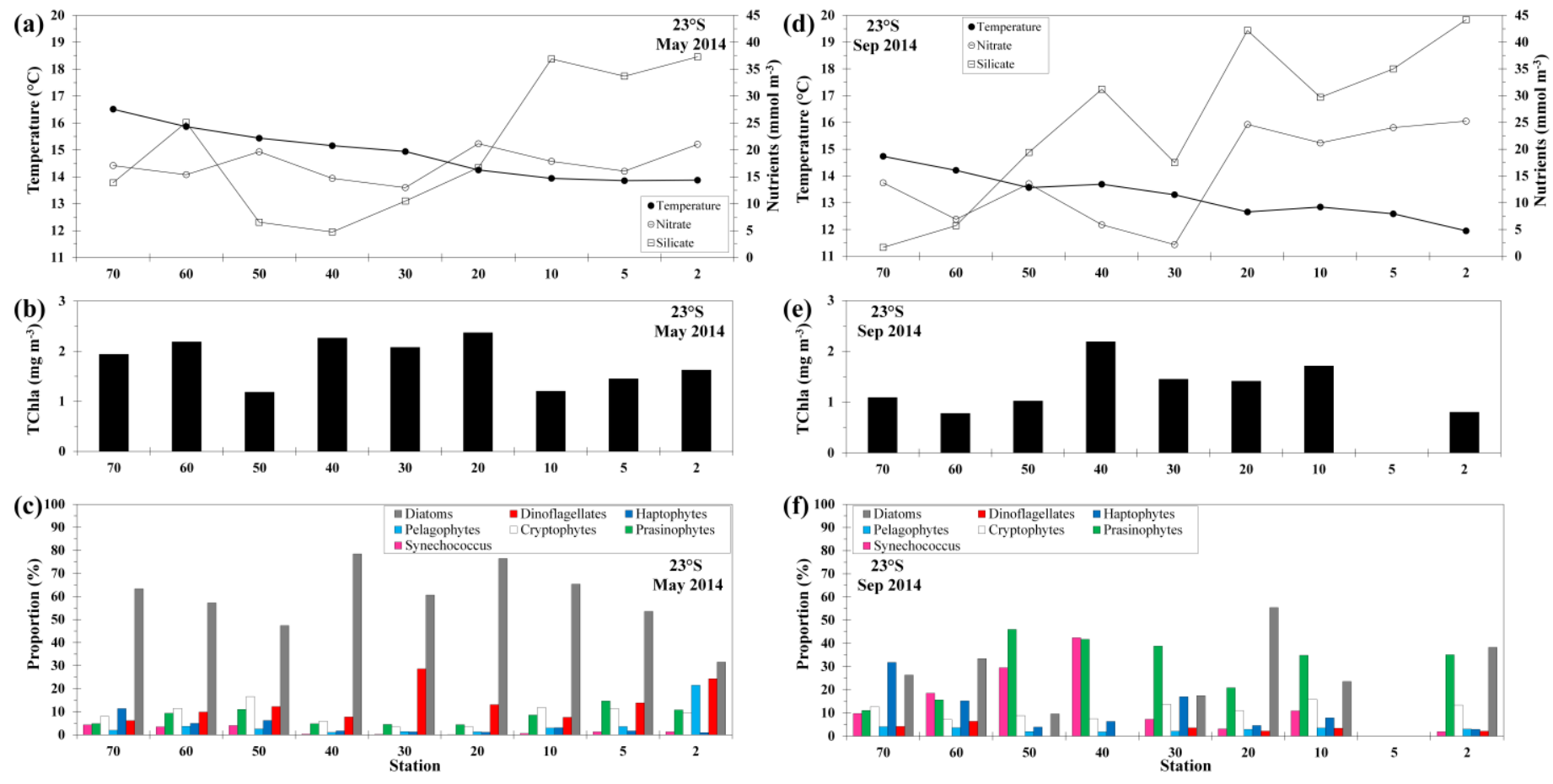
Fig. 8

813
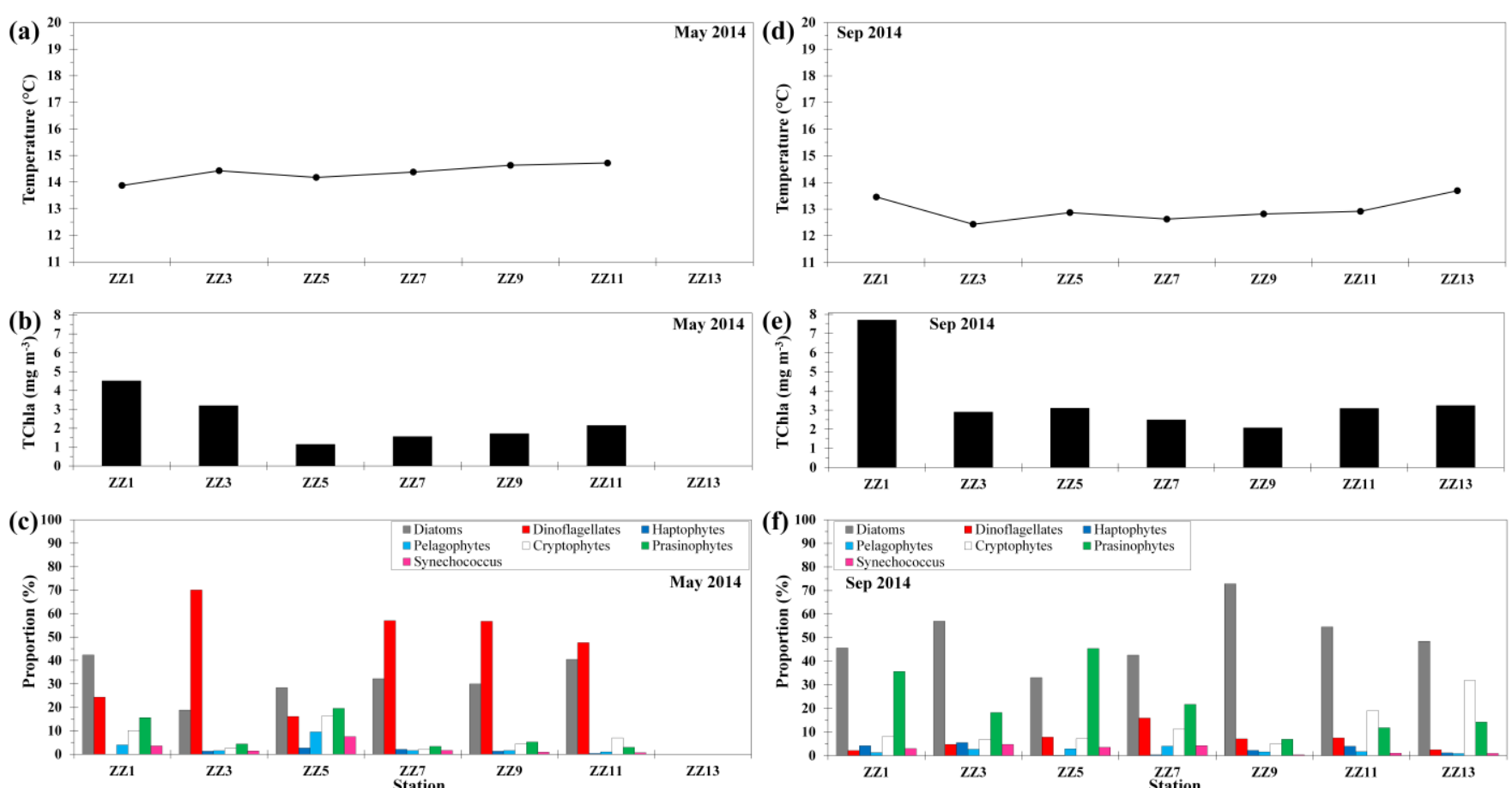

814

815

816

817

818

819

820
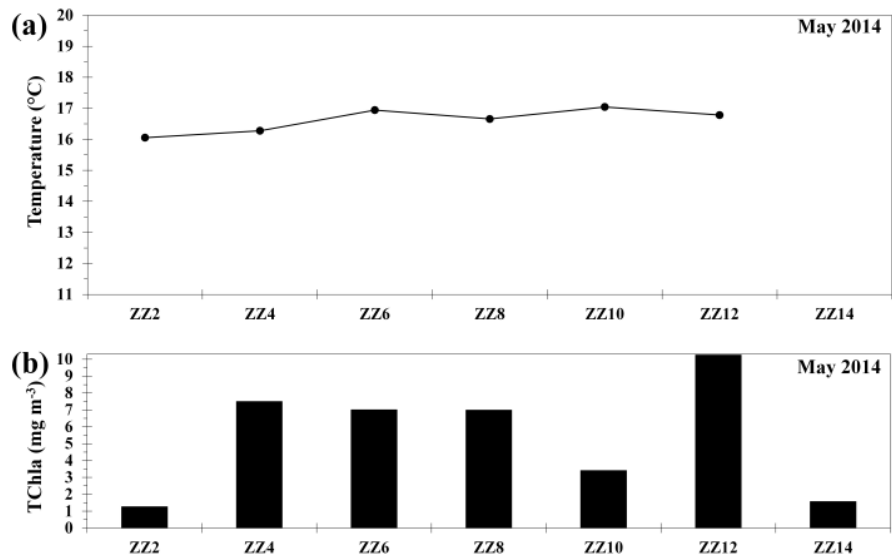

821

822

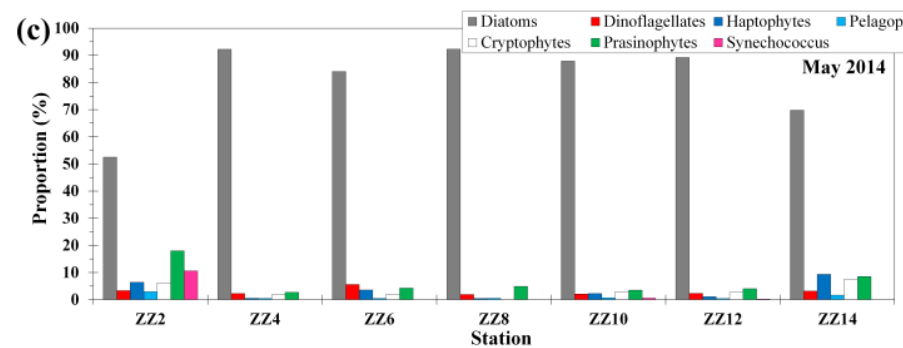

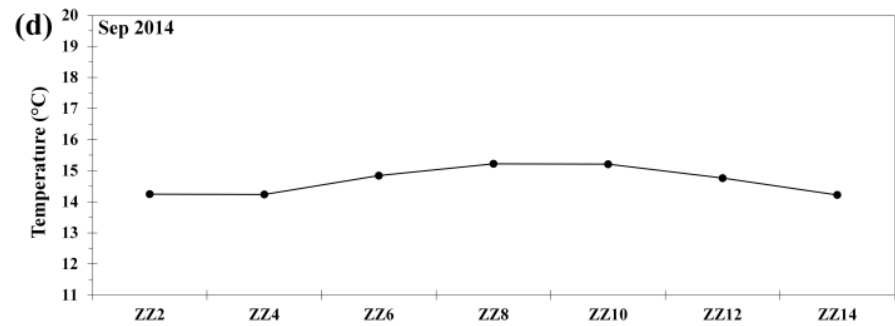
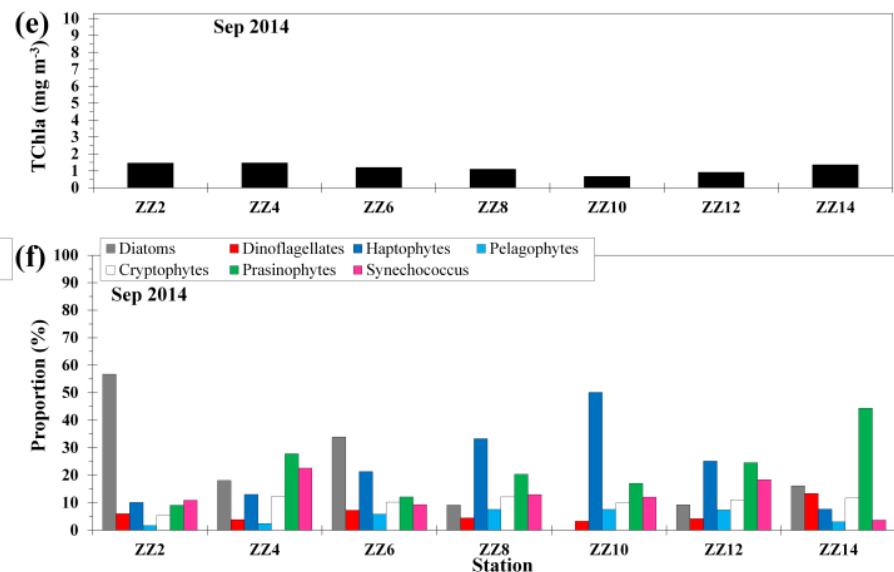